\title{
Oceanographic and Bathymetric Features as the Target for Pelagic MPA Design: A Case Study on the Cape of Gata
}

\author{
María Muñoz ${ }^{1, *}$, Andreas Reul ${ }^{1}$, María del Carmen García-Martínez ${ }^{2}$, Francisco Plaza ${ }^{3}$, \\ Begoña Bautista ${ }^{1}$, Francina Moya ${ }^{2}$ and Manuel Vargas-Yáñez ${ }^{2}$ \\ 1 Andalucía Tech, Departamento de Ecología y Geología, Universidad de Málaga, Campus de Teatinos s/n, \\ 29071 Málaga, Spain; areul@uma.es (A.R.); bbautista@uma.es (B.B.) \\ 2 Centro Oceanográfico de Málaga, Instituto Español de Oceanografía, Puerto Pesquero 21 s/n, Fuengirola, \\ 29640 Málaga, Spain; mcarmen.garcia@ieo.es (M.d.C.G.-M.); francina.moya@ieo.es (F.M.); \\ manolo.vargas@ieo.es (M.V.-Y.) \\ 3 Centro Oceanográfico de Gijón, Instituto Español de Oceanografía, Avenida Príncipe de Asturias, 70 Bis, \\ 33212 Gijón, Spain; francisco.plaza@ieo.es \\ * Correspondence: mariamunoz@uma.es; Tel.: +34-665-405-060
}

Received: 4 August 2018; Accepted: 2 October 2018; Published: 9 October 2018

\begin{abstract}
The Cape of Gata region (southeast Spain) allocates the thermo-haline Almeria-Oran front (AOF), which separates two biogeographical zones, with a very irregular bathymetry, consisting of two canyons and seamounts in an area of $100 \times 100 \mathrm{~km}$. An interdisciplinary oceanographic sampling strategy allowed us to solve mesoscale processes including current-bathymetry interactions. Subsurface fertilizing processes and elevated chlorophyll $a$ concentrations were found at the front, seamount, and submarine canyons, turning an apparently oligotrophic area into a rich one. According to a horizontal tracking simulation, the deep chlorophyll maximum (DCM) at the front is located above the pycnocline and travels fast offshore, transporting productivity from the fertilization process quickly from the region. The DCM at the seamount, in contrast, develops below the pycnocline and remains for almost three weeks in this area. In spite of the coastal marine protected areas (MPAs), a high surface nitrate concentration plume with its origin in a small coastal area without any protection was detected. Local circulation patterns and bathymetry-current interactions provide elevated productivity in surface water which is vertically connected to deep-sea fauna via the daily vertical migration of zooplankton, suggesting elevated biodiversity on the seamount and canyons of the area studied. Based on these results, and considering the presence of coastal MPAs and a Coastal Area Management Program, future studies on benthic fauna, an enlargement of coastal MPAs, and a transboundary land-deep-sea management program are suggested.
\end{abstract}

Keywords: seamount; fronts; fertilization; coastal water effluents; vertical connection; marine protected area; coastal management

\section{Introduction}

The Mediterranean Sea supports many endangered and endemic species, and it is an important hotspot for targeted conservation [1,2]. As an enclosed sea with low exchange rate, increasing intensity of human threats, unregulated development, and overexploitation, biodiversity along its coast is affected at all levels [2,3]. In order to protect the Mediterranean's biodiversity, the identification of sites to construct an ecologically representative network of marine protected areas (MPAs) in the Mediterranean is imperative and the objective of the United Nations Environment Program's Mediterranean Action Plan [4]. While benthic georeferenced diversity is generally used for MPA 
identification, low interest is given to the pelagic ecosystem, the biggest marine ecosystem, which connects all the others and provides the primary production that feeds the whole marine food web. Structures such as fronts [5,6], canyons [7-10], and seamounts [11] are described as sites of local fertilization due to the hydrodynamic processes that induce mixing of nutrient-rich water into the upper photic zone. The resulting increase in productivity attracts marine vertebrates such as turtles [12], tuna [13], marine mammals [14,15], and sharks [16]. According to Wingfield et al. [17], productive hotspots are linked to physical and geomorphological interactions that lead to the aggregation of primary and secondary producers, which in turn attract and ensure the persistence of top predators in the area $[18,19]$. In fact, fronts are described as indicators of pelagic diversity [20], channelling nutrients through multiple trophic levels including commercially important fish and marine mammals [21]. Top predators are usually $K$-strategic and endangered species, either because they are target species of fishing activities (tuna, swordfish) or due to accidental by-catch (marine mammals, turtles, and sharks). The aggregation of top predators, attracted by or growing on the local elevated productivity, is the main driving force for the protection of seamounts [22] and submarine canyons [23]. Additionally, vertical coupling between pelagic and deep-sea benthic ecosystems occurs on short time scales (several days down to $1400 \mathrm{~m}$ depth $[9,24]$ ), and shallow seamounts and ridges provide a direct link between the photic and deep-sea habitats positively affecting diversity, density, and behavior of benthic and pelagic organisms [25-27]. On the other hand, fronts, such as mobile features, are not usually protected, although fronts are the main migration routes of marine vertebrates and are suggested as priority conservation areas [28]. Generally, fronts [6,29], canyons [30], and seamounts [31] are studied separately, either due to the spatial distance between them (seamounts and canyons), or due to difficulties when studying a geographic referenced site (bathymetric feature) and a moving feature (front) at the same time. In order to simultaneously study and evaluate frontal-, canyon-, and seamount-linked fertilizing processes, a mesoscale resolving sampling was carried out in the waters around the Cape of Gata (southeast Spain, Figure 1). Under the quasi-persistent physical regime characterizing the Alboran Sea circulation [32,33], the sampled area provides an elevated probability to locate an intense thermo-haline front, the Almeria-Oran front ( $\mathrm{AOF}$ [33-35]) which is described as the eastern limit of the marine ecoregion "Alboran Sea" [35] and as a barrier of gene flow for some fish species [36]. Its most frequent position on the Spanish coast is around $2^{\circ}$ west [37]. The importance of the Garrucha Canyon for local pelagic productivity and its connection to deep-sea fauna was also described [9].

The present work focuses on the importance of seamounts and the AOF on local productivity and the need to protect such pelagic structures. The study area frequently comprises spatial and temporal features of conservation interest, such as persistence hydrographic structures, canyons, and seamounts, which enhance local productivity, and should be protected either by spatial or dynamic protected areas [38]. Based on the presence of coastal MPAs and a Coastal Area Management Program (CAMP) in the area, an MPA enlargement and a transboundary (from land to the deep sea) pilot program for sustainable management is proposed.

\section{Materials and Methods}

\subsection{Area of Study}

The study area is located on the south-eastern Mediterranean coast of Spain and comprises a cape (the Cape of Gata), two submarine canyons (the Cape of Gata Canyon and Garrucha Canyon), a submarine ridge (Abubacer High), and frequently, the thermo-haline front Almeria-Oran front (AOF) is located there (Figure 1). Atlantic modified water (salinity $<37.5$ ) is usually found to the west of the AOF and very modified Atlantic water (salinity > 37.5) to the east of the AOF. In the vertical dimension, the Atlantic-Mediterranean Interface separates the surface Atlantic water and the deeper Mediterranean water. 


\subsection{Sampling}

In order to sample the different water masses, circulation patterns, and physical-biological coupling in the area, a grid of 65 sampling stations covering two canyons (the Cape of Gata Canyon and Garrucha Canyon) and a seamount (Abubacer High) was sampled between 23 May 2011 and 30 May 2011 on board of the research vessel "Garcia del Cid" (Figure 1.) At each sampling station, a conductivity/temperature/depth device (CTD; Sea-Bird SBE 9, calibrated 11.02.2011) and carousel water sampler cast $(12$ Niskin bottles of $12 \mathrm{~L}$ ) were deployed. Discrete samples were taken at depths of $0,10,20,30,50,75,100,200$, and $300 \mathrm{~m}$ and at the depth of the fluorescence maximum for nutrient and chlorophyll $a$ analyses.

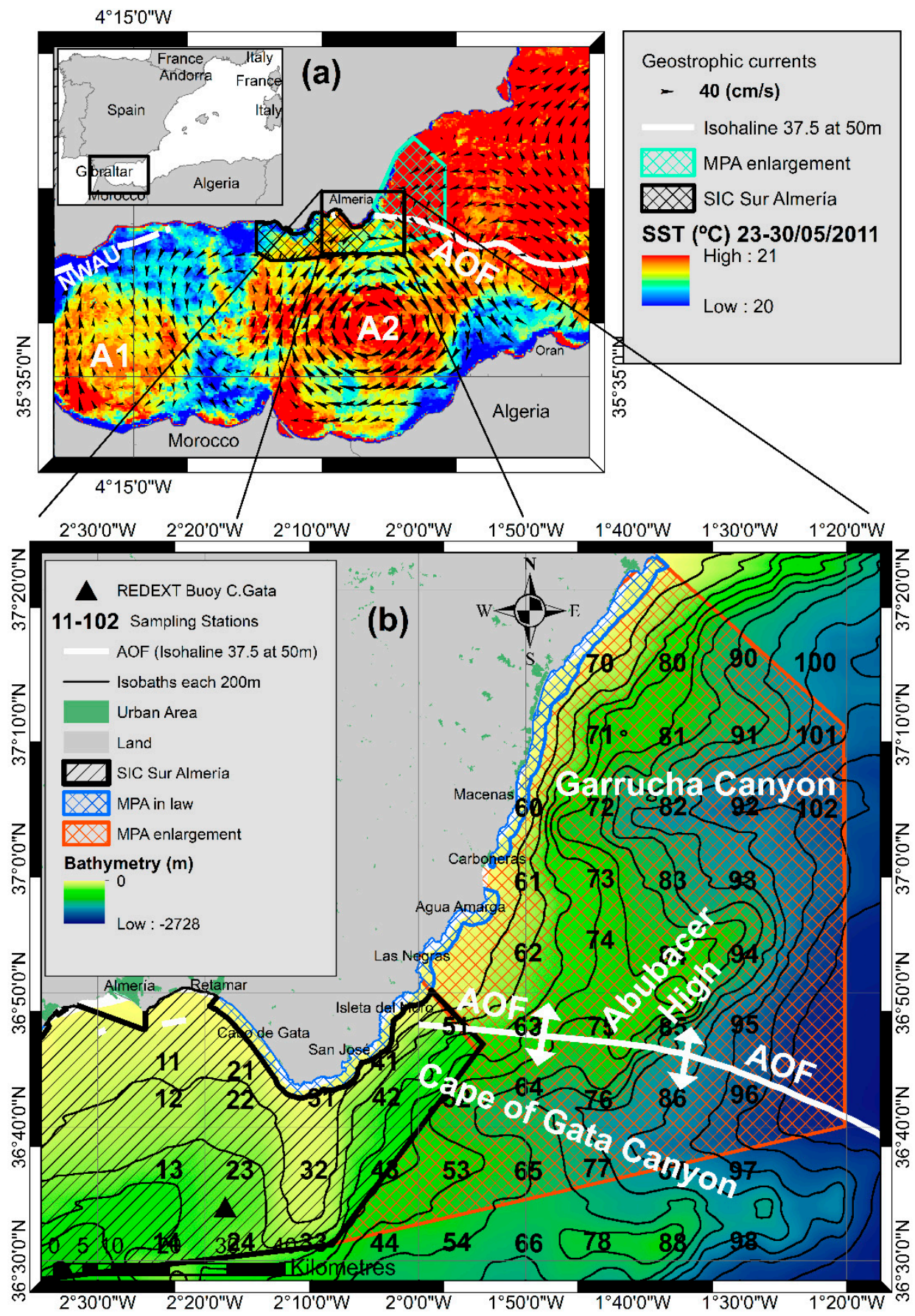

Figure 1. Cont. 


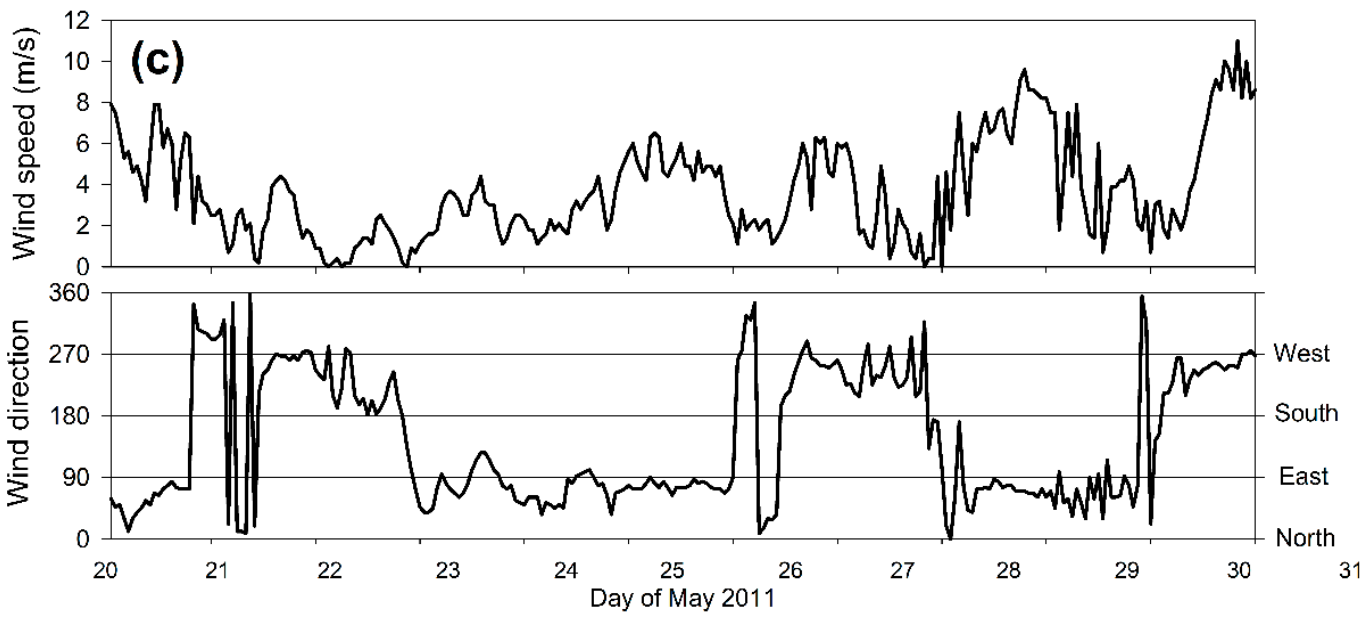

Figure 1. (a) Sea surface temperature (SST; weekly, composed 23-30 May 2011). North-western Alboran upwelling (NWAU), western (A1) and eastern (A2) anticyclonic gyre, and mean position of the isohaline 37.5 [39], indicating the haline signal of the Almeria-Oran front (AOF), the most probable geostrophic current profiles [32,37] showing strong currents from Almeria to Oran associated with the AOF, site of community importance (SIC) Sur Almeria, and the proposed enlargement of the marine protected area (MPA). (b) Sampling area, sampling station, and main bathymetric features (Cape of Gata Canyon, Garrucha Canyon, and Abubacer High) SIC Sur Almeria coastal MPA in law and proposed enlargement of the MPA. (c) Wind velocity and direction during the sampling period [40]. The coordinate system of all maps in the present work is the World Geographical System (WGS) 1984 Web Mercator (auxiliary sphere).

\subsection{Water Sample Analysis}

\subsubsection{Nutrient Analysis}

Water samples for nutrient analyses were kept in polyethylene vials rinsed with $5 \% \mathrm{HCl}$ and immediately frozen $\left(-20^{\circ} \mathrm{C}\right)$. Nitrate, phosphate, silicate, and nitrite concentrations were later analyzed in the laboratory with an autoanalyzer Brann-Leube AA3 following the method detailed in Reference [41].

\subsubsection{Chlorophyll $a$ Analysis}

Samples for estimating total chlorophyll $a(\mathrm{Chl} a ; 500 \mathrm{~mL})$ were filtered on board through Whatman grade GF/F glass microfiber filters $\left(0.7 \mu \mathrm{m}\right.$ pore size). The filters were frozen at $-20{ }^{\circ} \mathrm{C}$ and stored in the dark prior to the Chl $a$ analysis by fluorometry [42] using a Turner Design-10 fluorometer. Linear regression between $\mathrm{Chl} a$ concentration $\left(\mu \mathrm{g} \cdot \mathrm{L}^{-1}\right)$ measured at the discrete sampling depth and fluorescence (F, in arbitrary units (a.u.)) of the CTD was used to convert fluorescence into Chlorophyll $a(\mathrm{Chl} a)$ profiles $\left(\mathrm{Chl} a\left(\mathrm{mg} \cdot \mathrm{m}^{-3}\right)=0.0174+(0.688 \times \mathrm{F}(\mathrm{a} . \mathrm{u}).) ; r=0.802, n=395, p<0.001\right)$.

\subsection{Temperature, Salinity, and Current Fields}

Temperature, salinity (measured using the practical salinity scale), and potential density fields from the CTD were interpolated into a three-dimensional grid. Data were interpolated using an optimal statistical interpolation (OSI) method following the methods detailed in References [43-47]. Geostrophic currents were estimated from the density field using $200 \mathrm{dbar}$ as the reference level. Vertical velocities were estimated using the Omega equation $[48,49]$. 


\subsection{Currents}

Current profiles were measured with a vessel-mounted acoustic Doppler current profiler (VADCP) of $75 \mathrm{kHz}$ installed on board. The VADCP was configured to measure the currents at 71 discrete depths (number of bins) with a bin width of $10 \mathrm{~m}$, reaching a maximum depth of $700 \mathrm{~m}$. The mean ensemble frequency was $1 \mathrm{~min}$ based on direct measurements (pings) every second. The software used to pre-process (convert to engineering units and earth coordinates) and check VADCP data were the WINADCP and RDI tools. After the data files were downloaded and pre-processed, they were filtered and post-processed to get better-quality profiles and then interpolated with functions programmed in MATLAB language. Firstly, ensembles with a percent good less than $100 \%$ were removed, as well as those with an error velocity (the difference between vertical velocities computed using beam pairs) greater than a threshold. Secondly, the bottom signal was detected and removed from the affected transects (less than $700 \mathrm{~m}$ ). Then, the velocity data were checked in order to remove velocities with a value lower than the root mean square (RMS). Finally, they were interpolated on a regular (41 rows $\times$ 37 columns) grid. The interpolation of the ADCP current data was carried out by means of the same optimal or statistical interpolation technique used for CTD data interpolation.

\subsection{Particle Tracking}

As described in Reference [9], the interpolated ADCP currents for horizontal particle tracking were imported into Arcmap and converted to a $3109 \mathrm{~m} \times 3109 \mathrm{~m}$ cell size raster for velocity and direction (angle) file. Then, tracking was performed using a particle track tool with 25-m step length until it reached the limit of the current field. The particle-tracking algorithm used employs a predictor-corrector scheme of predicting the future location of a particle based on the local velocity field, as interpolated from the nearest raster cell centers [50]. The comparison of tracks with track intervals of 25, 250, and $2500 \mathrm{~m}$ (Annex 2 in Reference [9]) proved that the successive locations of the particles were not tied to the interval step.

\subsection{Plankton Density Patterns (ADCP Backscatter Strength)}

In order to obtain a high-resolution spatial and temporal pattern of plankton distribution and daily vertical migration, the relative backscattering strength of the Doppler signal was estimated according to the active sonar equation in the working version [51]. This model is used to relate the intensity of an ADCP echo to the scatters in the water and to solve the backscatter coefficient $\left(S_{v}\right)$ or backscattering strength in $\mathrm{dB}$.

$$
\left.S_{v}=C+10 \log _{10}\left(T_{X}+273.16\right) R^{2}\right)-L_{D B M}-P_{D B W}+2 \alpha R+K_{c}\left(E-E_{r}\right) .
$$

The constant $C(\mathrm{~dB})$ depends on the characteristics of the acoustic system employed, and $K c$ $\left(\mathrm{dB} \cdot\right.$ count $\left.^{-1}\right)$ is the received signal strength indicator (RSSI) scale factor; both constants are determined by linear regression between backscatter intensity from the RDI ADCP and sediment concentrations measured simultaneously with optical backscatter sensors (OBS) [52]. $L_{D B M}$ is the $10 \log _{10}$ (transmit pulse length, meters), $P_{D B W}$ is the $10 \log _{10}$ (transmit power, Watts), $T_{X}$ is the real-time temperature of the transducer $\left({ }^{\circ} \mathrm{C}\right), R$ is the range of the ensonified volume to the scatters in meters, $\alpha$ is the sound absorption coefficient $(\mathrm{dB} / \mathrm{m})$ and depends on salinity temperature and pressure variables, which are acquired with the CTD. $E$ (echo intensity; count) is the ADCP output for each cell along each beam, commonly called RSSI in RDI literature, $E_{r}$ is simply the RSSI value when there is no signal present, $\left.10 \log _{10}\left(T_{X}+273.16\right) R^{2}\right)$ is the term for transmission loss due to beam spreading, and $2 \alpha R$ is the term for loss due to absorption.

This method is a mix-up between qualitative and quantitative estimations, where stronger (less negative) $S_{v}$ indicates a higher concentration of suspended materials in the water column, among them, zooplankton. Zooplankton migration behavior in the region was described [9] in the Garrucha canyon, based on Longhurst-Hardy Plankton Recorder (LHPR) data. However, LHPR sampling is 
not possible at mesoscale resolution; therefore, in the present work, we used the backscatter signal as a proxy for zooplankton migration behavior at mesoscale, using surface oblique zooplankton hauls in the first $100 \mathrm{~m}$ for verification of elevated zooplankton concentration in surface water when less negative $\mathrm{dB}$ values were measured. As the backscatter diminishes with depth, a comparison of $S_{v}$ has to be carried out horizontally.

\subsection{Zooplankton Biovolume}

At each second sampling station of the sampling grid, oblique zooplankton hauls were carried out between $100 \mathrm{~m}$ and the surface, with an Aquatic Biotechnology Bongo 40 frame provided with a 100and 250- $\mu \mathrm{m}$ mesh, and General Oceanics flowmeters. Samples were fixed with buffered formaldehyde (4\% f.c.), until analysis in the laboratory. Zooplankton biovolume of the $250-\mu \mathrm{m}$ mesh was measured volumetrically by measuring water displacement in a graduated ( 250 and $25 \mathrm{~mL}$ ) cylinder following the methods of References [53,54].

\subsection{Bathymetry Data and Remote-Sensing Images}

Bathymetry data were downloaded from the National Oceanic and Atmospheric Administration (NOAA, [55]). The weekly composite sea surface temperature (SST) image was downloaded from the German Aerospace Center (DLR) [56].

\section{Results}

\subsection{Horizontal Patterns}

The weekly composed SST shows the north-western Alboran upwelling area characterized by cold water (Figure 1a). The western and eastern gyres (A1 and A2) of the Alboran sea are developed and characterized by warmer water in their inner parts. The study area (black square) was located at the north-eastern limit of the Alboran Sea. The SST gradient $\left(20-21^{\circ} \mathrm{C}\right)$ indicates the thermal signal of the AOF during the sampling period. The mean positon of the isohaline 37.5 shows the most probable position of the AOF, which is close to the weak thermal gradient shown in the satellite image in May (Figure 1a). The approximation to the study area (Figure 1b) shows that the position of the front is located between the Cape of Gata Canyon and Abubacer High (white line). The coldest water in the study area (deep-blue fringe east of the Cape of Gata shown in the black square Figure 1a) was observed along the western coast of the Cape of Gata. Wind speed during the sampling period was between 0 and $8 \mathrm{~m} \cdot \mathrm{s}^{-1}$ and very variable (Figure 1c), although a general pattern with increasing velocities from the beginning $\left(<4 \mathrm{~m} \cdot \mathrm{s}^{-1}, 21-24\right.$ May) to the end of the sampling period $\left(6-8 \mathrm{~m} \cdot \mathrm{s}^{-1}\right.$, 29-31 May) was observed. Wind direction changed from westerly (21-24 May) to easterly (24-27 May), a cycle which was repeated (westerly 27-29 May and easterly 29-31 May).

Direct measurements of temperature at surface water $(7 \mathrm{~m})$ corroborated the increase in sea surface temperature from southwest (SW) to northeast (NE) and colder water on the coast (Figure 2a). Surface salinity (Figure 2b) also increased from SW to NE. Lowest salinity values (36.54) were observed in the Bay of Almeria (westward of the Cape of Gata) which turns into saltier water (37.57) at San José. Nitrate concentrations were generally low, except for two stations (Stn 51 and Stn 52) in front of Las Negras, with values reaching up to $11.7 \mu \mathrm{M}$ (Figure 2c). This unusually high nitrate concentration was observed at several depths in the upper layer (0-30 m, see Section 3.2). Horizontal currents were strongest in front of the Cape of Gata $\left(0.43 \mathrm{~m} \cdot \mathrm{s}^{-1}\right)$ changing their direction from east to south (Figure 2c). Cyclonic and anticycyclonic gyres were observed at the Abubacer High and the Garrucha Canyon, respectively. Chl $a$ concentration was very low $\left(<0.18 \mathrm{mg} \cdot \mathrm{m}^{-3}\right)$, but higher $\mathrm{Chl} a$ concentration was observed westward of the Cape of Gata, specially in coastal waters between San José and Carboneras and to the north of the Garrucha canyon (Figure 2d). According to horizontal tracking, water crosses the sampling area from north (Stn 52) to south (Stn 67) in $57 \mathrm{~h}$ (Figure 2d). 

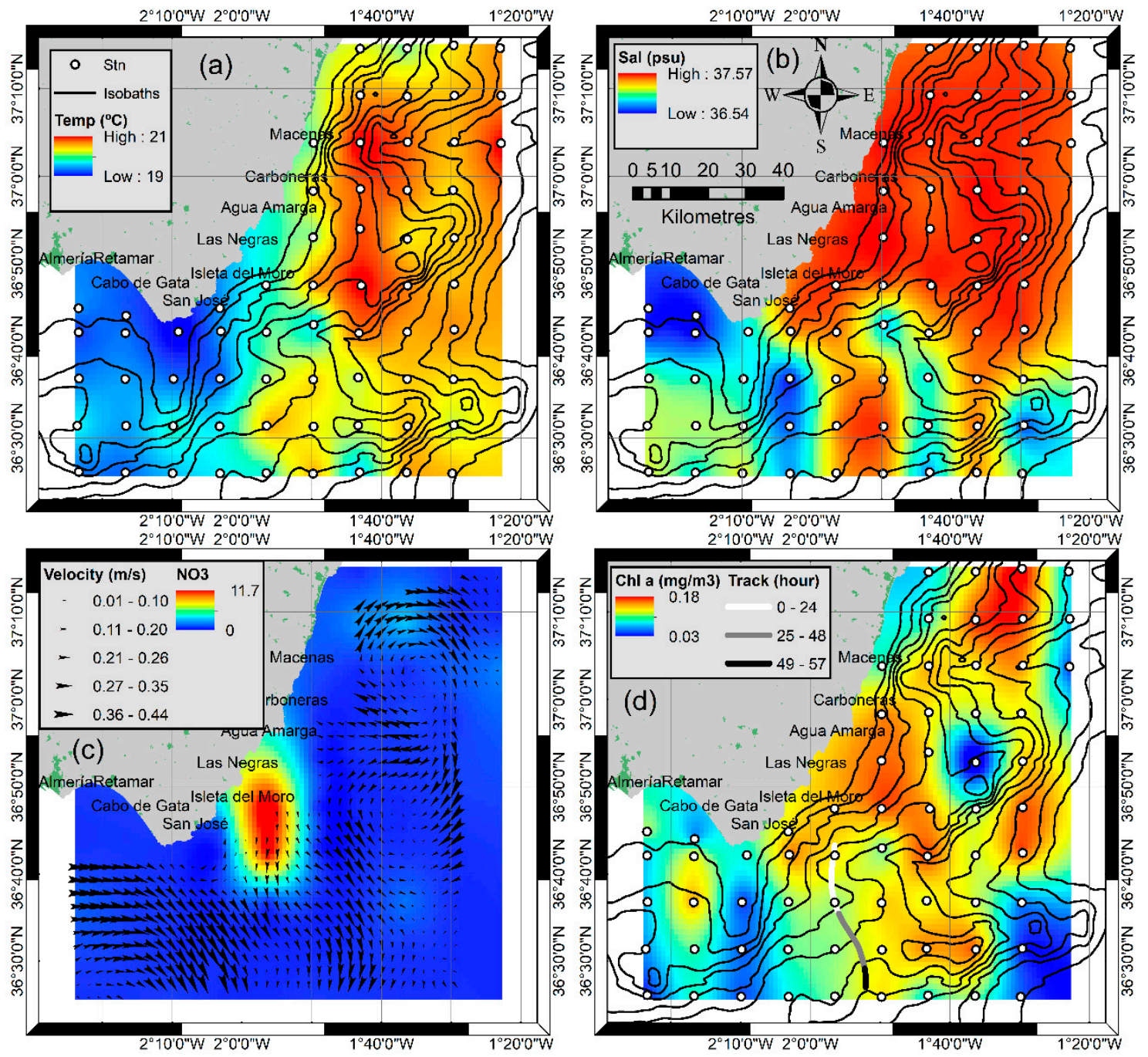

Figure 2. Spatial patterns at 7-m depth of (a) temperature $\left({ }^{\circ} \mathrm{C}\right),(\mathbf{b})$ salinity, (c) nitrate concentration $(\mu \mathrm{M})$ and horizontal currents $\left(\mathrm{m} \cdot \mathrm{s}^{-1}\right)$, and $(\mathrm{d})$ chlorophyll $a$ concentration $\left(\mathrm{mg} \cdot \mathrm{m}^{-3}\right)$ and horizontal particle track from longitude $1.942 \mathrm{~W}$ and latitude $36.722 \mathrm{~N}$ (Station (Stn) 52) at 7-m depth.

At $50-\mathrm{m}$ depth, warmer water $\left(19^{\circ} \mathrm{C}\right)$ was observed southwest of the Cape of Gata and close to the coast between San José and Las Negras (Figure 3a). In front of the Cape of Gata, the salinity shows a strong gradient from low salinity (36.88) to high salinity (38.05, Figure $3 b)$. This is the haline signal of the AOF. Nitrate concentrations were generally low, except for two offshore sampling stations located at the edge of the sampling grid (Figure 3c). It is remarkable that Stations 51 and 52 with very high nitrate concentrations at 7-m depth (Figure $2 \mathrm{c}$ ) do not show elevated nitrate concentrations at 50-m depth (Figure 3c). Horizontal currents were highest at the AOF following the shape of the salinity gradient (Figure 3b,c). Again, cyclone and anticyclone gyres were observed at Abubacer High and Garrucha Canyon, respectively. Chl $a$ concentration was almost one order of magnitude higher $\left(1.5 \mathrm{mg} \cdot \mathrm{m}^{-3}\right)$ than in surface waters $\left(0.18 \mathrm{mg} \cdot \mathrm{m}^{-3}\right)$, showing the highest $\mathrm{Chl} a$ concentrations associated with the AOF. According to horizontal tracking, a particle following the AOF passes through the sampling area in two days (Figure 3c). 


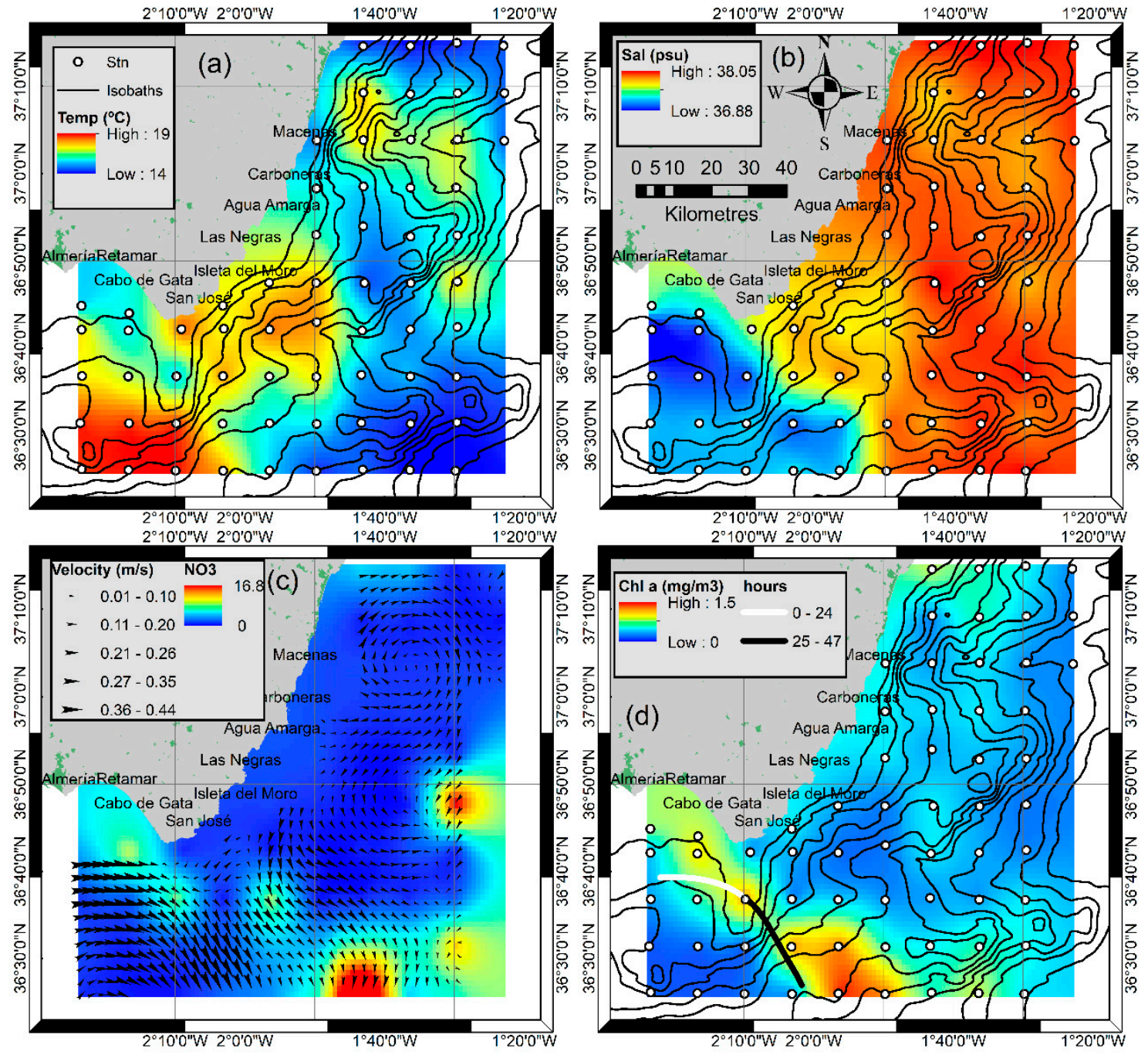

Figure 3. Spatial patterns at 50-m depth of (a) temperature $\left({ }^{\circ} \mathrm{C}\right)$, (b) salinity, (c) nitrate concentration $(\mu \mathrm{M})$ and horizontal currents $\left(\mathrm{m} \cdot \mathrm{s}^{-1}\right)$, and $(\mathrm{d})$ chlorophyll $a$ concentration $\left(\mathrm{mg} \cdot \mathrm{m}^{-3}\right)$ and horizontal particle track from longitude $2.367 \mathrm{~W}$ and latitude $36.655 \mathrm{~N}$ (between Stn 12 and Stn 13) at 50-m depth. Note that scales in Figures 2 and 3 are different; temperature decreases, salinity increases, and notably, chlorophyll $a$ concentration increases one order of magnitude.

At 75 -m depth, warm water $\left(16^{\circ} \mathrm{C}\right)$ was limited to the south-western part of the sampling grid (Figure 4a). The haline front was located farther to the west (Figure $4 \mathrm{~b}$ ). Nitrate concentrations were low, except for two sampling stations at the edge of the grid. Horizontal currents showed a similar pattern to the one at 50-m depth, but velocities decreased. Lowest horizontal currents were located just above Abubacer High. Chl $a$ concentrations were higher in the south-western (associated with the AOF) and north-eastern (northward of the Garrucha Canyon) corners of the sampling grid. Additionally, an elevated $\mathrm{Chl} a$ concentration $\left(1.0 \mathrm{mg} \cdot \mathrm{m}^{-3}\right)$ was observed at Abubacer High. According to horizontal tracking at 75-m depth, this deep chlorophyll maximum (DCM) remained at Abubacer High for 23 days (Figure $4 \mathrm{~d}$ ). 

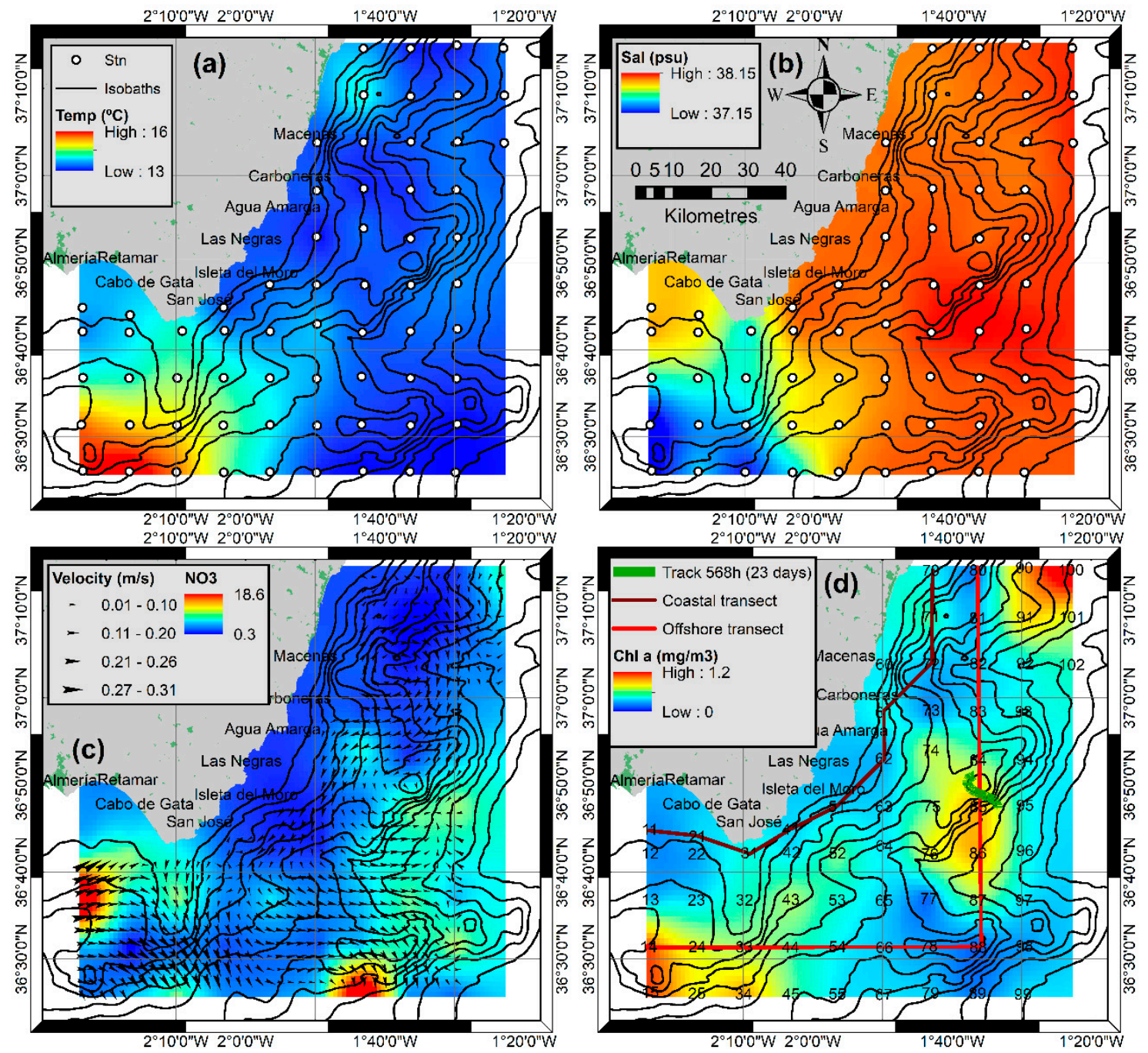

Figure 4. Spatial patterns at 75-m depth of (a) temperature $\left({ }^{\circ} \mathrm{C}\right)$, (b) salinity, (c) nitrate concentration $(\mu \mathrm{M})$ and horizontal currents $\left(\mathrm{m} \cdot \mathrm{s}^{-1}\right)$, and $(\mathbf{d})$ chlorophyll $a\left(\mathrm{mg} \cdot \mathrm{m}^{-3}\right)$ concentrations and horizontal particle track from longitude $1.616 \mathrm{~W}$ and latitude $36.851 \mathrm{~N}$ (Stn 65) at 75-m depth. Red and dark-red lines in Figure $4 \mathrm{~d}$ indicate the offshore and coastal transect shown in Figures 5 and 6, respectively. The offshore transect is divided into two legs. Leg 1 is from Stn 14 to Stn 88 and leg 2 is from Stn 88 to Stn 80. Note that scales in Figures 3 and 4 are different; temperature decreases, salinity increases, and chlorophyll $a$ concentration remains one order of magnitude higher than at surface (Figure 2).

\subsection{Vertical Patterns}

In order to show the underlying processes that can explain the described horizontal distribution patterns, two vertical transects showing temperature, salinity, nitrate concentration, and Chl $a$ concentration were chosen: (i) a coastal transect following the sampling stations next to the coast (dark-red line, Figure 4d) and (ii) an offshore transect (light-red line, Figure 4d) crossing the AOF from west to east (leg 1, Stn 14-88) and the Abubacer High from south to north (leg 2, Stn 88-80). 
The offshore transect shows a deepening thermocline (following the isotherm of $18^{\circ} \mathrm{C}$, from $50 \mathrm{~m}$ to $75 \mathrm{~m}$ ) from east to west (Stn 88 to Stn 14, Figure 5a), while, in the north-south direction (Stn 80 to Stn 88), the thermocline was located at 50-m depth. The most intense DCM was observed at leg 1 with $2.1 \mathrm{mg} \cdot \mathrm{m}^{-3}$ associated with the thermocline. At leg 2 , the highest $\mathrm{Chl} a$ concentration was $1.2 \mathrm{mg} \cdot \mathrm{m}^{-3}$, and, in contrast to leg 1, the DCM was located below the thermocline. Vertical salinity and nitrate transects (Figure 5b) show the haline gradient of the AOF at Stn 54, and the Atlantic-Mediterranean interface (AMI; salinity 37.0-37.5) can be observed. The AMI reaches the surface at Stn 54, and deepens from 50-75 m westward. At leg 2 (Stn 88 to Stn 80), the AMI water reaches the surface. At Stn 85, more haline (>37.5) surface waters appear, corresponding to very modified Atlantic waters of the Gulf of Vera. Under these conditions, the DCM was encountered just below the thermocline. It is worth noting that, just above the Abubacer High (Stn 85), the DCM is deeper (95 m) than elsewhere, and doming isotherms and isohalines (Figure $5 a, b$ ) suggest upward motion and fertilizing processes. In fact, increasing and shoaling nitrate concentrations were observed above the Abubacer High (Figure 5b, Stn 85).

Along the coastal transect, the thermocline remained at a depth of $50 \mathrm{~m}$ (Figure 6a). The DCM was associated with the thermocline throughout the transect, reaching its highest value $\left(1 \mathrm{mg} \cdot \mathrm{m}^{-3}\right)$ eastward of the spur of the Cape of Gata, where isotherms indicate the position of the AOF, which is confirmed by the haline gradient encountered at Stn 31 located just above the spur of the Cape of Gata (Figure $7 \mathrm{~b})$. Nitrate concentrations were low in the first $20 \mathrm{~m}(<0.54 \mu \mathrm{M})$ except for station 51 where nitrate concentrations between 11.9-13.6 $\mu \mathrm{M}$ were observed in the upper $20 \mathrm{~m}$. Also, Stn 71 showed elevated nitrate concentrations $(1.6-5.9 \mu \mathrm{M})$ in the sea surface. The singular coastal nitrate maximum observed at Stn 52 was also observed at Stn 51 (Figure 2c). These surface nitrate concentrations were higher than those found in the first $200 \mathrm{~m}$.

The vertical sigma-t, Chl a concentration, and nutrient profile at Stn 51 and Stn 52 (Figure 7a,b) show low nutrient concentrations and a DCM of $0.6-0.7 \mathrm{mg} \cdot \mathrm{m}^{-3}$ below the pycnocline $(50-75 \mathrm{~m})$; nutrient concentration increased with depth. However, the highest nitrate concentration was observed in surface water $(0-20 \mathrm{~m})$, just above an intense pycnocline. Furthermore, surface nutrient concentrations (specially nitrate) were the highest concentrations observed in the first $200 \mathrm{~m}$. The Temperature-salinity (TS) diagrams of both sampling stations (Figure 7c,d) show that the elevated nitrate concentrations were associated with less haline $(<37.53)$ and warmer water $\left(>19^{\circ} \mathrm{C}\right)$ of the TS profile. In particular, Stn 52 shows decreasing salinity at the surface. Thus, the elevated nitrate concentrations were associated with less haline and warmer water with lower density located in the first $20 \mathrm{~m}$. The fact that these high nitrate concentrations are separated from deeper waters by a strong pycnocline at a depth of $50 \mathrm{~m}$ and are associated with a second density minimum at a depth of $20 \mathrm{~m}$ (Figure $7 \mathrm{a}, \mathrm{b}$ ) suggests that the nutrient-rich water does not come from vertical mixing, but is associated with advection of warmer, less haline, and nutrient-rich water of an unknown origin. 

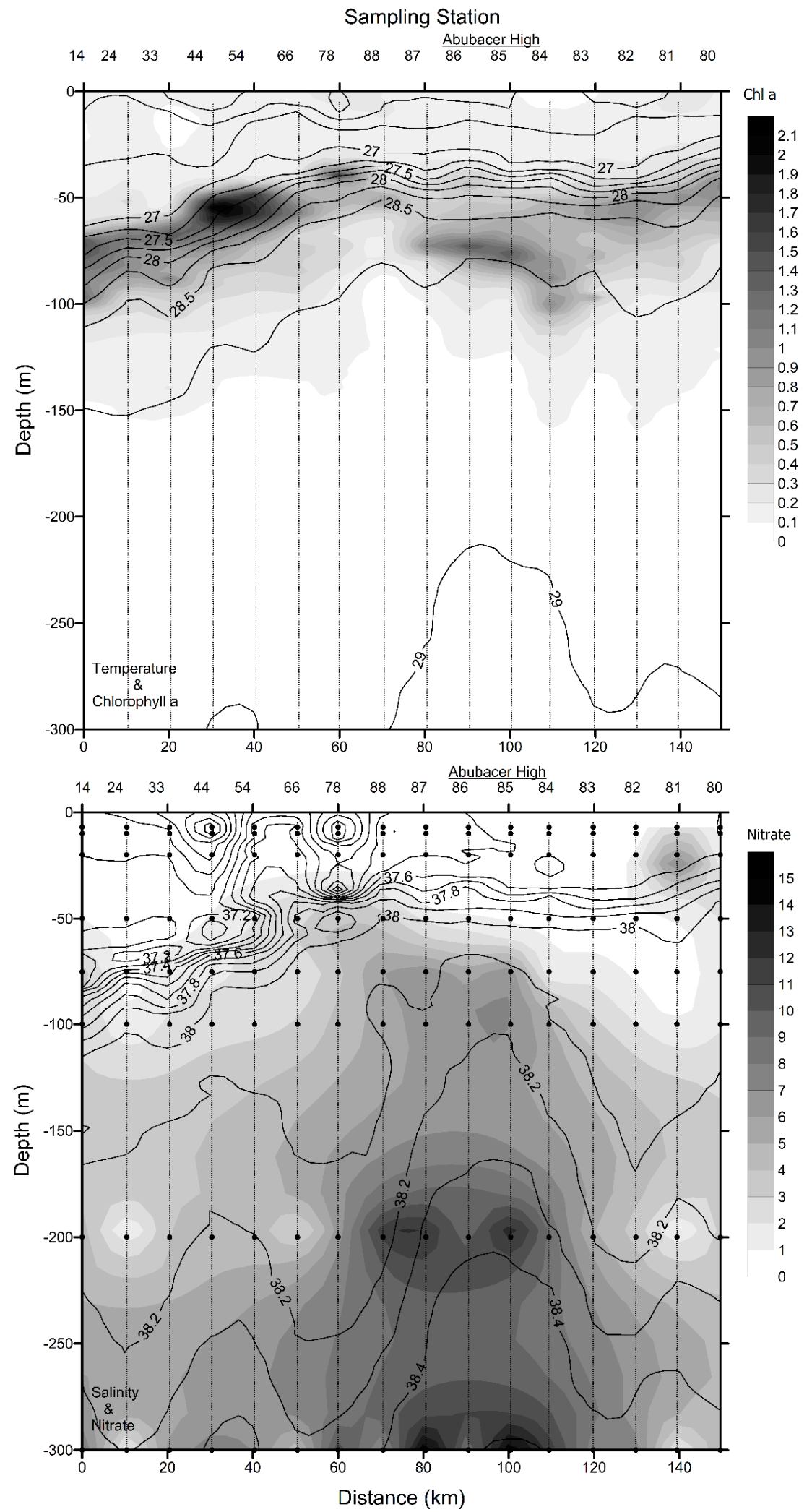

Figure 5. Offshore transect crossing the AOF (leg 1, Stn 14 to Stn 88) and the Abubacer High (leg 2, Stn 88 to Stn 80$)$. (a) Temperature $\left({ }^{\circ} \mathrm{C}\right.$, black labelled lines) and chlorophyll $a$ concentration $\left(\mathrm{mg} \cdot \mathrm{m}^{-3}\right.$, greyscale); (b) salinity (black labelled lines) and nitrate concentration ( $\mu \mathrm{M}$, greyscale). 

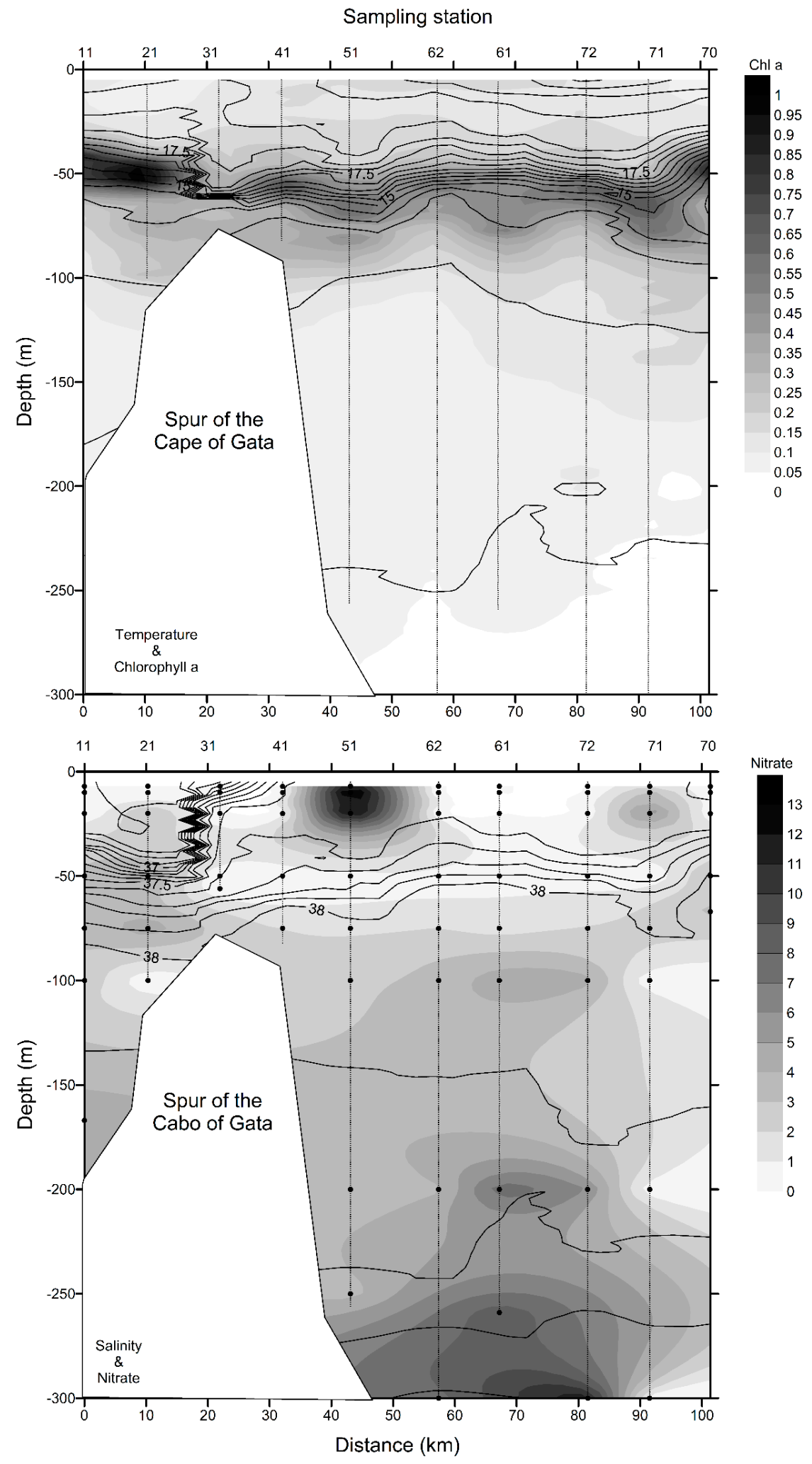

Figure 6. Coastal transect (Stn 11 to Stn 70). (a) Temperature $\left({ }^{\circ} \mathrm{C}\right.$, black labelled lines) and chlorophyll a concentration $\left(\mathrm{mg} \cdot \mathrm{m}^{-3}\right.$, greyscale); (b) salinity (black labelled lines) and nitrate concentration ( $\mu \mathrm{M}$, greyscale). 

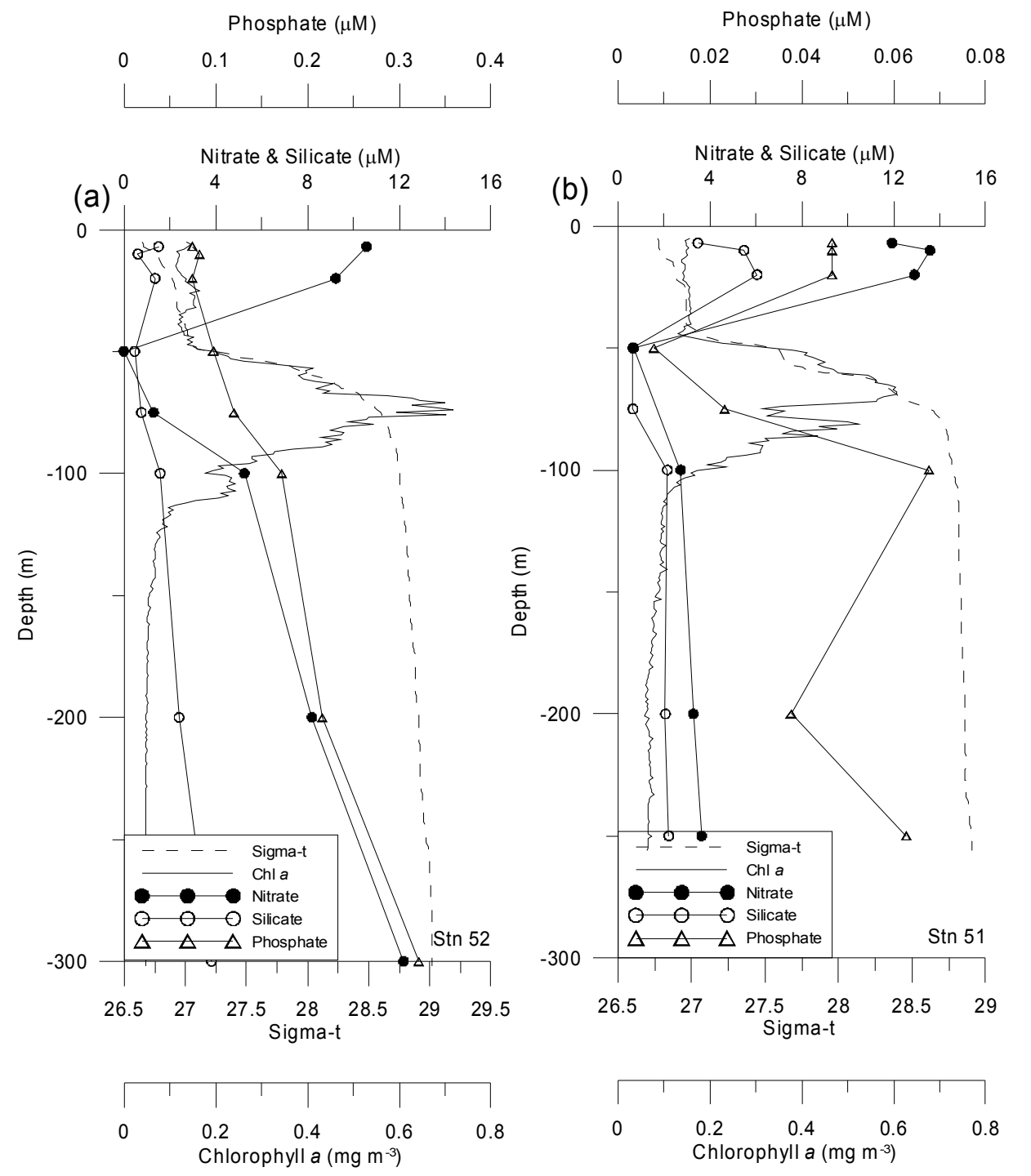

(c)

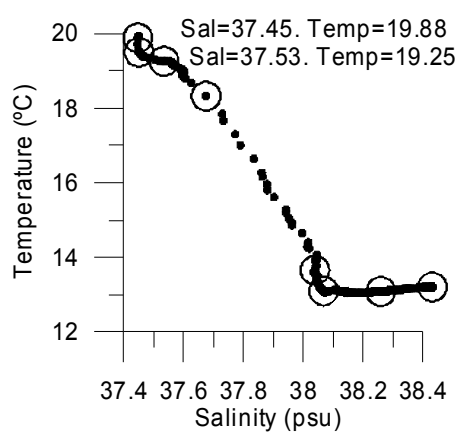

(d)
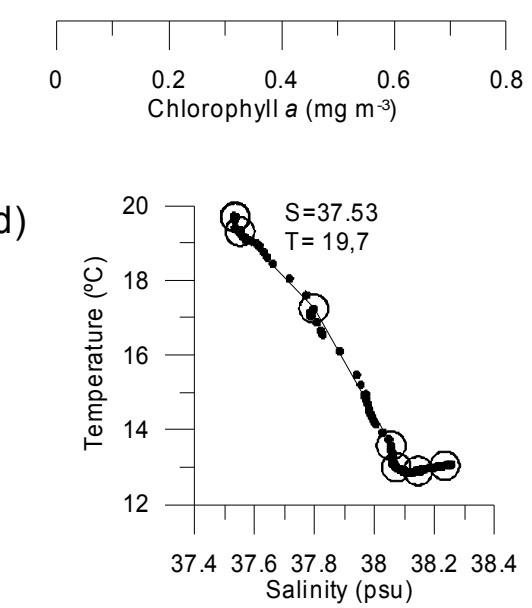

Figure 7. Vertical profile of density (sigma-t), and Chl $a$ and nutrient concentrations (a) at $\operatorname{Stn} 52$, and (b) at Stn 51. Temperature-salinity (TS) diagrams (c) at Stn 52, and (d) at Stn 51. 


\subsection{Zooplankton Distribution and Vertical Connection}

Zooplankton biovolume in the first $100 \mathrm{~m}$ (bottom to surface at shallower stations) was the highest in the Bay of Almeria (76 mL per $1000 \mathrm{~m}^{3}$, at 12:00 p.m. Greenwich Mean Time (GMT)), and in coastal water at the head of the submarine canyon of San Jose during the night $\left(62 \mathrm{~mL}\right.$ per $1000 \mathrm{~m}^{3}, 12: 27 \mathrm{a} . \mathrm{m}$. GMT). Both values were located to the west of or at the AOF, indicated by the salinity gradient at the DCM (Figure 8a). To the east of the AOF, the highest zooplankton biovolume in the first $100 \mathrm{~m}$ was observed during the night $\left(23 \mathrm{~mL}\right.$ per $1000 \mathrm{~m}^{3}$, at 8:20 p.m. GMT; $35 \mathrm{~mL}$ per $1000 \mathrm{~m}^{3}$, at 11:30 p.m. GMT) next to the Abubacer High. During the day, the highest biovolume concentration was found at a coastal station $\left(20 \mathrm{~mL}\right.$ per $1000 \mathrm{~m}^{3}$, at 10:15 a.m. GMT) and again at Abubacer High (18 mL per $1000 \mathrm{~m}^{3}$, at 12:13 p.m. GMT). Thus, we can observe that zooplankton biovolume is higher in Almeria Bay, in coastal water, and at Abubacer High, especially during the night. The backscatter strength of the Doppler signal between sampling stations 55 and 90 (Figure 9b) shows a complete diurnal cycle, crossing next to the Abubacer High. Elevated zooplankton biovolume at Abubacer High during the night coincides with higher backscatter signals in the first $100 \mathrm{~m}$ (Figure 8a,b). The backscatter signal suggests a daily cycle where higher backscatter signals down to $400 \mathrm{~m}$ were observed at 6:00 p.m. and 5:00 a.m. GMT. The more intense backscatter signal than in the surrounding water observed down to $400 \mathrm{~m}$ indicates the presence of zooplankton, which was finally observed at midnight in the zooplankton sampling of the first $100 \mathrm{~m}$. Thus, we suggest a daily vertical migration (DVM) cycle connecting the DCM located in the upper $100 \mathrm{~m}$ with deeper water in the area, as schematically indicated by the white discontinuous arrow in Figure $8 \mathrm{~b}$. 


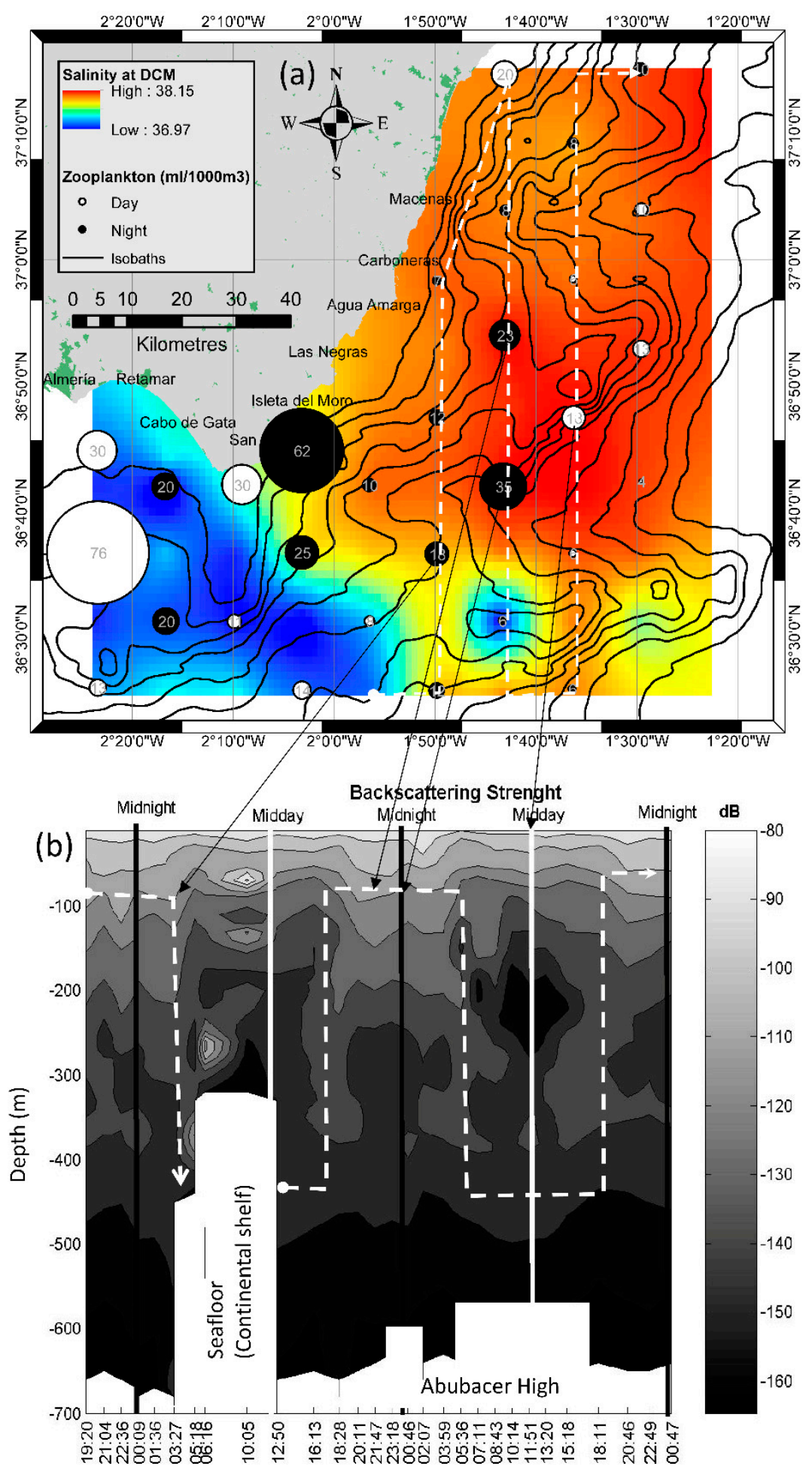

Time GMT (25.05-28.05.2011)

Figure 8. (a) Spatial distribution of zooplankton biovolume concentration (mL per $1000 \mathrm{~m}^{3}$ ) in the first $100 \mathrm{~m}$ of the water column. The white dotted line indicates the transect of the vertical backscatter transect shown in (b). (b) The vertical backscatter signal between Stn 55 and 90 indicates the daily vertical migration (DVM) of zooplankton. Stronger (less negative) backscatter (dB) indicates higher plankton concentration [52]. The white dotted line schematically indicates the zooplankton migration behavior along the backscatter transect shown in Figure 8a. 


\section{Discussion}

\subsection{Pelagic Patterns of Local Fertilization}

The importance of the AOF offshore was described in terms of Chl $a$ [57], zooplankton concentration [58], and particle subduction [59]. The present study shows the importance of the AOF in terms of $\mathrm{Chl} a$ concentration in coastal waters of the area studied. Apart from the Garrucha Canyon [10] and the AOF [60], the present work shows a third Chl-a-rich area where fertilizing processes take place: the Abubacer High. Fertilizing processes linked to topography-current interactions were described for seamounts [11] and submarine canyons [7-10], while fertilizing processes at fronts $[29,61,62]$ are related to ageostrophic vertical circulation associated with the frontal structure.

The DCMs at the AOF and above the Abubacer High are not only different in the underlying fertilizing processes but also in their fate. While the DCM at the front drifts away in 2-3 days, the DCM at the Abubacer High remains in the area for 2-3 weeks. The Chl $a$ concentration at the DCM $\left(1-2 \mathrm{mg} \cdot \mathrm{m}^{-3}\right)$ in the area studied is similar to that observed in the Gulf of Cadiz [63] and the Alboran Sea [6]. Also, the depth-averaged $\mathrm{Chl} a$ concentration $\left(0.47 \mathrm{mg} \cdot \mathrm{m}^{-3}, 0-100 \mathrm{~m}\right)$ is similar to other recognized fertile areas such as the Gulf of Cadiz [63,64], and about half of those at the northwest (NW) Alboran upwelling ( $1 \mathrm{mg} \cdot \mathrm{m}^{-3}$ in the spring and summer [6]). As productive areas, the front, the Abubacer High, and the Garrucha Canyon are important for fisheries $[13,26,65,66]$. Furthermore, in the Mediterranean, fronts with salinity values between 36.9 and 37.7 are preferred spawning areas of Bluefin tuna [65], a description that fits with the characteristics of the AOF. In contrast to a front, the fertilizing processes related to topography-current interactions are less variable, while $\mathrm{Chl} a$ concentration around the Cape of Gata might be less variable in space and time than in other places, such as the wind-driven upwelling in the North Alboran sea, which could be a reason for this area being known as a feeding ground for larvae and young tuna (Thunnus thynnus and Sarda sarda [67]).

Taylor columns above seamounts [68], and hydrodynamics in the canyons allow zooplankton and larvae to remain in the fertile, nutrient-rich area. Through DVM, zooplankton remain during the day in low-moving water and graze at midnight at the DCM acting as a conveyer belt between surface primary productivity and deep-sea fauna $[10,69,70]$, providing optimal conditions for abundant and diverse deep-sea fauna, as well as the presence of top predators [26,38].

Thus, the presence of a haline front, seamount, and two submarine canyons in a small area of about $100 \times 100 \mathrm{~km}$ is an exceptional feature in the Mediterranean Sea. Each of these features is worth protection on its own: seamounts $[22,27,71]$, submarine canyons $[23,72,73]$, and fronts $[20,28]$. 


\subsection{Local Economy and Megafauna}

Fishery is an important factor for local economy of the studied area. Red shrimp (Arsiteus antennatus) is a species of fishery interest [74] and makes up to 71\% of the economic value of fish catch [75] in the region. While multispecific fishing grounds are closer to the coast, trawling on Aristeus antennatus is carried out at depths between 500-800 m and located farther offshore [76], comprising the canyons and the Abubacer High (Figure 9a). In spite of the proximity of coastal MPAs and the importance of fishery for the area, little scientific knowledge exists about benthic invertebrates of the canyons. Deep-sea trawling affects deep-sea fauna either directly by retrieving organisms [77] or indirectly due to sediment suspension [78]. A recent study [79] revealed some insight of invertebrates at the top of Abubacer High, where Gorgonian gardens, black corals, and the recently described mollusk, Neopycnodonte zibrowii [80], were detailed. Even though lost fishnets were observed on top of Abubacer High, and scientific knowledge about the pelagic community around Abubacer High is still unknown [81], analyzing five submarine canyons [30] found the highest species richness of megafauna between 400-700 m, and Reference [82] describes differences in deep-sea fish assemblage on seamounts at scales of several km. Accordingly benthic fauna and deep-sea fish in the study area should be studied in the future in order to prevent potential diversity loss and loss of unknown endemism or undescribed species. Furthermore, productivity hotspots like fronts, canyons, and seamounts persistently attract top predators such as sharks, tuna, and cetacean [17,70,83-85], which feature a K-stratagem, whereby most of them are endangered.

The combination of high depth and productivity associated with the canyons is the motive for the presence of cetacean in that sampling area. The Cuvier's beaked whale (Ziphius cavirostris) is a predominantly oceanic species often associated with habitats of steep slopes and with marked preference for submarine canyons and cliffs [86,87]. In the Alboran Sea, these whales are distributed in waters of more than 600-m depth and slopes over $4 \%$, and are especially frequent on the isobath of $1000 \mathrm{~m}$ in an area of submarine canyons next to Almeria [14]. Apart from Cuvier's beaked whales, sperm whales (Physeter macrocephalus) were also observed at the head of the Cape of Gata, and especially along the axis of the Garrucha Canyon (Figure 9b). The use of these canyons as a habitat for the cetacean enters in conflict with the use of the area for naval military submarine exercises (Figure 9b). In addition, with 35,000 ships per year, the Cape of Gata is third in Spanish marine traffic (after the Strait of Gibraltar and Finisterre), which is regulated with a special device at 17-21 nautical miles off the Spanish coast. In 2001, almost 210-800 million tons of petrol were transported through the Alboran Sea [88]. The fact that several ship routes come together in front of the Cape of Gata bears an elevated possibility of a naval accident. 

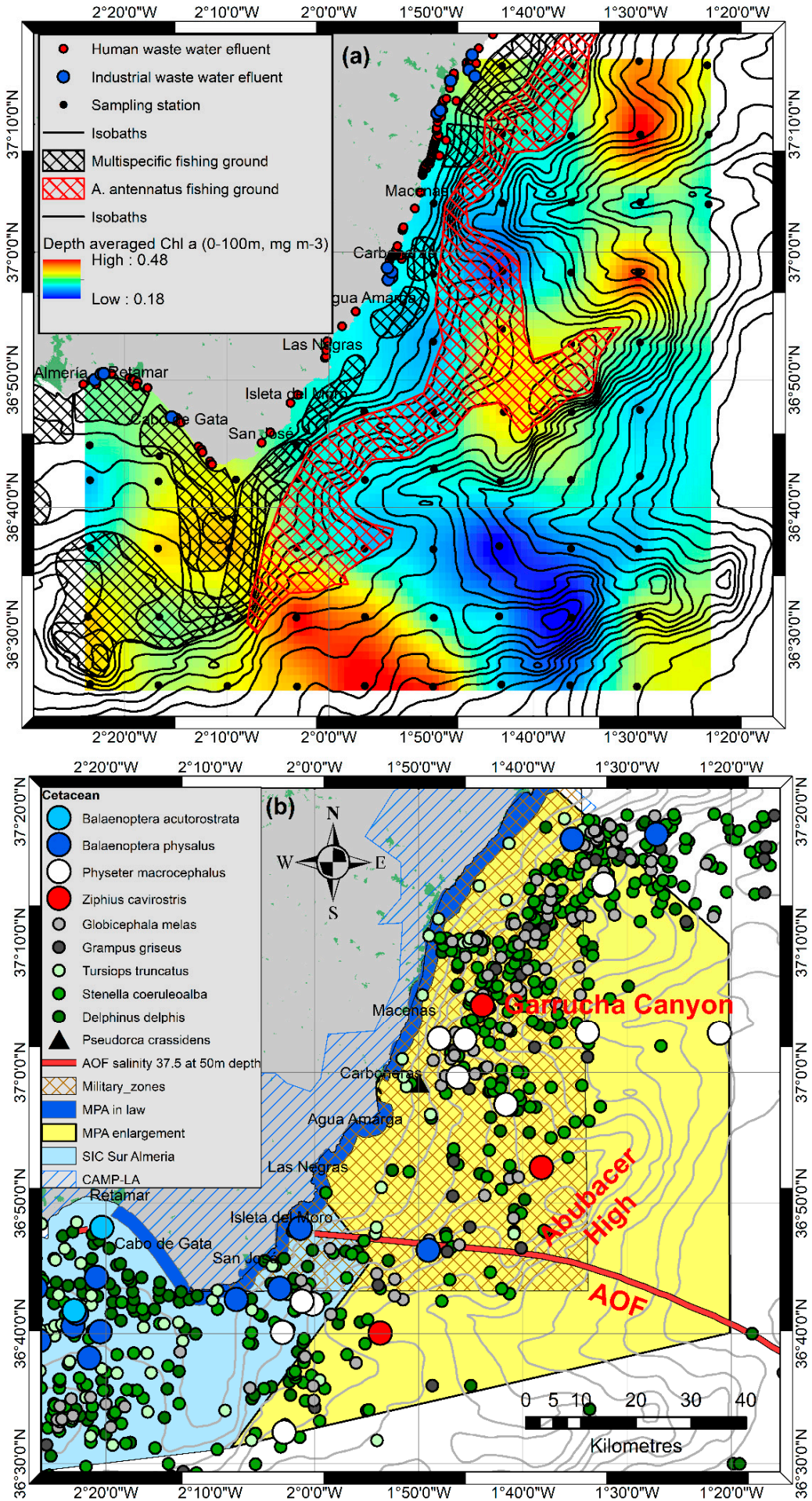

Figure 9. (a) Depth-averaged $(0-100 \mathrm{~m})$ chlorophyll $a$ concentration $\left(\mathrm{mg} \cdot \mathrm{m}^{-3}\right)$, sites of human and industrial effluents [89], and fishing grounds [76,90]. (b) Coastal Area Management Program Levante Almeriense (CAMP-LA), existing Marine Protected Areas (MPAs), and proposed enlargement of the MPA. Presence of cetacean species (Balaenoptera acutorostrata (minke whale), Balaenoptera physalus (fin whale), Physeter microcephalus (sperm whale), Ziphius cavirostris (Cuvier's beaked whale), Globicephala melas (long-finned pilot whale), Grampus griseus (Risso's dolphin), Tursiops truncatus (common bottlenose dolphin), Stenella coeruleoalba (striped dolphin), Delphinus delphis (short-beaked common dolphin), and Pseudorca crassidens (false killer whale) [91]. 


\subsection{Coastal Waters and Effluents}

Due to the high temperature at the surface, the high nitrate concentration and low salinity surface waters at Stn 51 and 52 are not explicable by the upwelling of nutrient-rich water. Additionally, the strong pycnocline observed at those stations and the higher nitrate concentrations than those observed in the first $200 \mathrm{~m}$ suggest that the high nitrate concentration might be a sign of coastal effluents. Lots of human wastewater effluents are located along the coast (Figure 9a) and some industrial wastewater effluents (thermal power station and desalination plant, among others) are located at Carboneras, the unique coastal site without marine protection along the coast covered by the coastal MPAs (Figure 9b). The thermal power station and desalination plant effluents are mixed and released with a salinity similar to the mean salinity encountered at the releasing point (0.9-1.1 of the mean salinity found in the area [92]). Nitrate concentrations are about $700 \mu \mathrm{g} \cdot \mathrm{L}^{-1}(11.3 \mu \mathrm{M})$ [90]. These nitrate concentrations are in the range of the very high nitrate concentrations observed in surface waters at $25 \mathrm{~km}(\mathrm{Stn} 51)$ and $38 \mathrm{~km}$ (Stn 52) to the south of Carboneras (Figures 2 and 7a,b). According to Reference [93], currents and coastal sediment transport to the east of the Cape of Gata flow southeastward. Main circulation patterns offshore also flow southeastward until meeting the AOF [10,37]. Thus, the origin of the less dense and nitrate-rich water observed at Stn 51 and Stn 52 might be the signal of the mixed desalination plant and thermal power station effluents, causing eutrophication of oligotrophic surface waters. The environmental effect of wastewater plumes, in terms of extension, duration, and effect on the pelagic community, is of increasing concern and requires multidisciplinary studies [94]. In order to confirm our observations and evaluate the potential impact of wastewater plumes in the area, remote-sensing detection of wastewater plumes [95] should be carried out in the area in the future.

\subsection{MPA Enlargement and Transboundary Management Program}

The Cape of Gata area is a recognized limit between two biogeographical zones [38,96]. Its elevated diversity along the coast was the driving force for establishing the terrestrial-marine protected area, the Cape of Gata $[97,98]$, and later on the adjacent special area of conservation (SAC), Fondos Marinos Levante Almeriense [99]. Additionally, an open-water MPA (site of community importance, SIC) was recently established to the west of the Cape of Gata (Seco de los Olivos Sur de Almeria [100]). This MPA just reaches the limit of the Alboran Sea, the AOF, and the head of the Cape of Gata Canyon. The ecoregion of the Gulf of Vera, east of the AOF, lacks an offshore MPA [35], although the prominent Garrucha Canyon is located there. Additionally, References $[10,37]$ show the horizontal and vertical connectivity in that area and its importance for marine spatial planning. Recently, Reference [101] showed the importance of connectivity for MPA design and preservation of small-ranged species at the Mediterranean scale, and identified the Cape of Gata area as a priority MPA, especially if larval dispersal was considered. Furthermore, the present study shows the importance of vertical connectivity in the region, particularly at Abubacer High. In the final report of the Coastal Area Management Program Levante Almeriense (CAMP-LA), the extension of the CAMP-LA offshore, more scientific information about submarine canyons and seamounts, where important local fishery takes place, is claimed [102].

The described current bathymetry interaction increases local productivity attracting top predators and deep-sea fauna close to the coast. Deep-sea fauna is less known and has lower resilience against human impacts. We urgently encourage the study of deep-sea fauna in the area in order to fill the gap of scientific knowledge. Nevertheless, according to the principle of precaution, we already propose the enlargement of the SIC Sur de Almeria/Seco de los Olivos to the east, in order to cover the AOF, Cape of Gata Canyon, Abubacer High, and Garrucha Canyon (Figure 9b). Each of these features is worth protection in itself. Seamounts, especially shallow ones, support rich diverse endemic fauna with a high degree of endemism and K-strategic fish assemblages [103-105]. To globally protect biodiversity, seamounts should count with a protective regime and be declared as fishery no-take zones [104]. In order to facilitate the selection of seamounts being considered in an MPA network, a global seamount classification based on abiotic environmental variables was proposed [106]. 
Submarine canyons provide rich faunal communities, spawning and nursery areas, and refugees, while attracting megafauna; they provide ecosystem services (provisioning, regulation, and cultural) and are treated by human activities such as fishing and oil gas exploitation, and are sinks for litter and marine pollution [73]. The Convention on Biological Diversity suggested that submarine canyons could be classified as priority areas for conservation [73,102]. Finally, both habitat and species associated with submarine canyons and seamounts are considered in the Dark Habitat Action Plan [4].

The fact that the coast of the area studied is already protected facilitates the enlargement of the offshore MPA covering seamounts and canyons. Possible conflicts with local fisheries at Abubacer High could be resolved. The 25-year-long experience of fishery reserves of the Alboran Island, with licenses for red shrimp exploitation, demonstrate positive feedback for both MPAs and fishery activity [107]. Further conflicts could be marine traffic and military use (Figure 9b). Marine traffic routes were changed in 2006 [108] in order to protect the Cape of Gata area and cetaceans. Similar changes could be made in the future if necessary. The main interference with cetaceans, especially Cuvier's beaked whale and sperm whale, would be military submarine exercises (Figure 9b). It is worth mentioning that Cuvier's beaked whale is considered in Annex 2 of the protocol for specially protected areas of Mediterranean importance (SPAMI) declaration, and the whole Gulf of Vera was recently declared as an important marine mammal area [109]. The proposed enlargement of the existing SIC Sur de Almeria/Seco de los Olivos could be a priority area for protecting whales in the Gulf of Vera. In order to resolve military and conservation conflicts, the extent of the military area should be moved to other regions or be reduced considerably. Additionally, dynamic ocean management [110] could be applied, looking for the most suitable time window for military exercises, minimizing the harmful effect on the cetacean population.

Management and benefits of land-sea conservation planning were shown by ÁlvarezRomero et al. [111], and, from an economical point of view, the final document of the CAMP-LA [102] project claims to extend the CAMP area to open ocean waters because important resources (red shrimp, Aristeus antennatus) for local economy are located there. The proposed enlargement would protect singular marine ecosystems in front of the CAMP-LA area. The CAMP-LA and the SIC Sur de Almeria/Seco de los Olivos require their management plans. If MPA enlargement is accepted, a joint management program could be achieved and the CAMP can be converted into the first integrated coastal area deep-ocean management program (ICADOMP), considering horizontal, vertical, land, coastal, and deep-sea connectivity [10].

The combination of MPA and management programs provides a suitable framework to assess zonation and potential uses of the extended MPA. The management plan of the SIC Almeria/Seco de los Olivos which was declared in 2014 [100], and which we propose to be extended, is currently being elaborated in the framework of the European Union (EU) INTERMARES project [112]. The management plan of the extended area should be elaborated considering the revenue of main fishery activity (red shrimp fishery, first sale at Garrucha fish market in 2017 was 1.6 million $€$ without subtracting fishery costs [113]) and potential new activities such as whale watching, which, for example, at Tarifa (Strait of Gibraltar) in 2016 moved 107,900 passengers and obtained a total net benefit of 2.6 million $€$ [114]. Moreover, it should be taken into account that the coastal area is already an MPA which facilitates the establishment of the enlargement, due to the fact that coastal conflicts and benefits of MPA are already resolved. The existing tourism associated with protected areas provides a large number of potential whale watchers, or customers interested in other leisure activities. Furthermore, the recovery of target species [115] and a 10\% increase of fisheries will benefit from the waters near the potentially closed areas by spill-over of bigger target species [116] which could improve fishery activity in the long term. The examples exposed above show that the MPA enlargement could be of economic benefit for the region, where conversion of fishery activity into the whale-watching industry could provide protection, education, and economic benefits. Apart from the suggestions in the present work, an exhaustive local socioeconomic study should be carried out in order to elaborate the management plan, including local boats and fishermen involved in the future whale-watching industry. 
Considering a terrestrial area of $3376.3 \mathrm{~km}^{2}$ (CAMP-LA area) and a marine area of 10,618.4 $\mathrm{km}^{2}$ (marine part of SACs the Cape of Gata $=188.1 \mathrm{~km}^{2}$, Fondos Levante Almeriense $=167.8 \mathrm{~km}^{2}$, SIC Sur de Almeria $/$ Seco de los Olivos $=4408.2 \mathrm{~km}^{2}$, and the proposed enlargement $=5854.3 \mathrm{~km}^{2}$ ), it would be an ambitious pilot project, achieving, for the first time, a sustainable and ecosystem-based management from land to deep-sea ecosystems. Although the Marine Strategy Framework Directive [117], Marine Spatial Planning Directive [118], Water Framework Directive [119]. and Blue Growth Strategy [120,121] determine the framework of future sustainable development, to our knowledge, it requires a transboundary pilot project from land to deep-sea, which is lacking at the moment. Joining the CAMP-LA area with existing MPAs and the enlargement proposed provide an optimal framework for conservation and sustainable development from land to deep sea, covering canyons, seamounts, and fronts. The particular bathymetry, oceanography, and already declared CAMP and MPAs provide a suitable framework for establishing a unique and necessary pilot project on transboundary sustainable management at an EU level.

\section{Conclusions}

The irregular bathymetry, presence of the AOF, and associated currents provide the area around the Cape of Gata with phytoplanktonic biomass higher than that observed at surface waters. The presence of three fertilizing sites (front, canyons, and seamounts) in an area of $100 \times 100 \mathrm{~km}$ is exceptional in the Mediterranean Sea and provides enhanced primary production throughout the year attracting top predators. Phytoplankton biomass remains at the seamount, feeding local zooplankton and benthic organisms. The economic importance of local fishery (Arsiteus antennatus), the benthic biodiversity at hotspots (canyons and seamounts), the presence of coastal MPAs and a management program, as well as the unique oceanographic and bathymetric features of this region, suggest the enlargement of existing MPAs based on a precautionary principle. Benthic studies should be carried out soon in the canyons and on the seamount. The presence of a coastal management program (CAMP-LA) and adjacent MPAs provides a suitable framework for establishing a transboundary management program from land to deep-sea waters.

Author Contributions: Conceptualization, M.M. Data curation, M.M., A.R., M.d.C.G.-M., F.P., B.B., and F.M. Formal analysis, A.R., M.d.C.G.-M., F.P., and B.B. Funding acquisition, A.R. and M.V.-Y. Methodology, M.M. and M.V.-Y. Software, M.M., F.P., and M.V.-Y. Supervision, A.R. and M.V.-Y. Visualization, M.M. Writing-original draft, M.M. Writing—review and editing, M.M., A.R., M.d.C.G.-M., F.P., B.B., F.M., and M.V.-Y.

Funding: This study was financed by the Spanish national project DESMONN (CTM2008-05695-C02-01) and subproject CETI (CTM2008-05695-C02-02.).

Acknowledgments: We thank the research vessel Garcia del Cid, the crew, the Spanish Oceanographic Institute and research group (RNM-192, University of Málaga) members for sampling assistance. We also thank an anonymous reviewer for the use of English style.

Conflicts of Interest: The authors declare no conflicts of interest.

\section{References}

1. Danovaro, R.; Corinaldesi, C.; D’Onghia, G.; Galil, B.; Gambi, C.; Gooday, A.J.; Lampadariou, N.; Luna, G.N.; Morigi, C.; Olu, K.; et al. Deep-Sea biodiversity in the Mediterranean Sea: The known, the unknown, and the unknowable. PLoS ONE 2010, 5, e11832. [CrossRef] [PubMed]

2. Mouillot, D.; Albouy, C.; Guilhaumon, F.; BenRaisLasram, F.; Coll, M.; Devictor, V.; Meynard, C.N.; Pauly, D.; Tomasini, J.A.; Troussellier, M.; et al. Protected and threatened components of fish biodiversity in the Mediterranean Sea. Curr. Biol. 2011, 21, 1044-1050. [CrossRef] [PubMed]

3. Laubier, L. Mediterranean Sea and humans: Improving a conflictual partnership. In The Handbook of Environmental Chemistry; Saliot, A., Ed.; Springer: Berlin, Germany, 2005; pp. 3-28, ISBN 978-3-540-25018-0. 
4. UNEP-MAP-RAC/SPA. Action plan for the conservation of habitats and species associated with seamounts, underwater caves and canyons, aphotic hard beds and chemo-synthetic phenomena in the Mediterranean Sea. In Dark Habitat Action Plan; RAC/SPA: Tunis, Tunisia, 2015; p. 17. Available online: http:/ /www.racspa.org/dark_habitats (accessed on 25 May 2018).

5. Sarhan, T.; García-Lafuente, J.; Vargas, M.; Vargas, J.M.; Plaza, F. Upwelling mechanisms in the Northwestern Alboran Sea. J. Mar. Syst. 2000, 23, 317-331. [CrossRef]

6. Reul, A.; Rodríguez, V.; Jimenez-Gomez, F.; Blanco, J.M.; Bautista, B.; Sarhan, T.; Guerrero, F.; Ruíz, J.; García-Lafuente, J. Variability in the spatio-temporal distribution and size-structure of phytoplankton across an upwelling area in the NW-Alboran Sea (W.-Mediterranean). Cont. Shelf Res. 2005, 25, 589-608. [CrossRef]

7. Skliris, N.; Hecq, J.H.; Djenidi, S. Water fluxes at an ocean margin in the presence of a submarine canyon. J. Mar. Syst. 2002, 32, 239-251. [CrossRef]

8. Palanques, A.; García-Ladona, E.; Gomis, D.; Martín, J.; Marcos, M.; Pascual, A.; Puig, P.; Pili, J.-M.; Emelianov, M.; Monserrat, S.; et al. General patterns of circulation pattern, sediment fluxes and ecology of the Palámos (La Fonera) submarine canyon, northwestern Mediterranean. Prog. Oceanogr. 2005, 66, 89-119. [CrossRef]

9. Muñoz, M.; Reul, A.; Vargas-Yáñez, M.; Plaza, F.; Bautista, B.; García-Martínez, M.C.; Moya, F.; Gómez-Moreno, M.-L.; Fernandes, J.A.; Rodríguez, V. Fertilization and connectivity in the Garrucha Canyon (SE-Spain) implications for Marine Spatial Planning. Mar. Environ. Res. 2017, 126, 45-68. [CrossRef] [PubMed]

10. Skliris, N.; Djenidi, S. Plankton dynamic controlled by hydrodynamic processes near a submarine canyon of NW Corsican coast: A numerical modelling study. Cont. Shelf Res. 2006, 26, 1336-1358. [CrossRef]

11. Vargas-Yáñez, M.; Sarhan, T.; Plaza, F.; Rubín, J.P.; García-Martínez, C. The influence of tide-topography interaction on low-frequency heat and nutrient fluxes. Application to Cape Trafalgar. Cont. Shelf Res. 2002, 22, 115-139. [CrossRef]

12. Schillinger, G.L.; Palacios, D.M.; Bailey, H.; Bogard, S.J.; Swithenbank, A.M.; Gaspar, P.; Wallace, B.P.; Spotila, J.R.; Paladino, F.V.; Piedra, R.; et al. Persistent Leatherback Turtle Migrations Present Opportunities for Conservation. PLoS Biol. 2008, 6, e171. [CrossRef] [PubMed]

13. Morato, T.; Hoyle, S.D.; Allain, V.; Nicol, S.J. Seamounts are hotspots of pelagic biodiversity in the open ocean. Proc. Natl. Acad. Sci. USA 2010, 107, 9707-9711. [CrossRef] [PubMed]

14. Cañadas, A.; Sagarminaga, R.; de Stephanis, R.; Urquiola, E.; Hammond, P.S. Habitat selection models as a conservation tool: Proposal of marine protected areas for cetaceans in Southern Spain. Aquat. Conserv. Mar. Freshw. Ecosyst. 2005, 15, 495-521. [CrossRef]

15. Pascual, M.; Borja, A.; Vanden Eede, S.; Deneudt, K.; Vincx, M.; Galparsoro, I.; Legorburu, I. Marine biological valuation mapping of the Basque continental shelf (Bay of Biscay), within the context of marine spatial planning. Estuar. Coast. Shelf Sci. 2011, 95, 186-198. [CrossRef]

16. Litvinov, F. Fish Visitors to Seamounts: Aggregations of Large Pelagic Sharks Above Seamounts. In Seamounts: Ecology, Fisheries \& Conservation; Pitcher, T.J., Morato, T., Hart, P.J.B., Clark, M.R., Haggan, N., Santos, R.S., Eds.; Blackwell Publishing Ltd.: Oxford, UK, 2007; pp. 202-206. [CrossRef]

17. Wingfield, D.K.; Peckham, S.H.; Foley, D.G.; Palacios, D.M.; Lavaniegos, B.E.; Durazo, R.; Nichols, W.J.; Croll, D.A.; Bogard, S.J. The making of productivity hotspot in coastal ocean. PLoS ONE 2011, 6, E27874. [CrossRef] [PubMed]

18. Worm, B.; Lotze, H.K.; Myers, R.A. Predator diversity hotspots in the blue ocean. Proc. Natl. Acad. Sci. USA 2003, 100, 9884-9888. [CrossRef] [PubMed]

19. Morato, T.; Varkey, D.A.; Damasco, C.; Machete, M.; Santos, M.; Prieto, R.; Santos, R.S.; Pitcher, T.J. Evidence of a seamount effect on aggregating visitors. Mar. Ecol. Prog. Ser. 2008, 357, 23-32. [CrossRef]

20. Miller, P.I.; Christodoulou, S. Frequent locations of oceanic fronts as an indicator of pelagic diversity: Application to marine protected areas and renewables. Mar. Policy 2014, 45, 318-329. [CrossRef]

21. Woodson, C.B.; Litvin, S.Y. Fronts drive fishery production. Proc. Natl. Acad. Sci. USA. 2015, 112, 1710-1715. [CrossRef] [PubMed]

22. Clark, M.R.; Schlacher, T.A.; Rowden, A.A.; Stocks, K.I.; Consalvey, M. Science Priorities for Seamounts: Research Links to Conservation and Management. PLoS ONE 2012, 7, E29232. [CrossRef] [PubMed] 
23. Würtz, M. Mediterranean Submarine Canyons: Ecology and Governance; IUCN: Gland, Switzerland; Málaga, Spain, 2012; p. 211, ISBN 978-2-8317-1469-1. Available online: https:/ /www.iucn.org/content/mediterraneansubmarine-canyons-ecology-and-governance (accessed on 28 July 2018).

24. Graf, G. Benthic pelagic coupling in a deep-sea benthic community. Nature 1989, 341, 437-439. [CrossRef]

25. Morato, T.; Bulman, C.; Pitcher, T.J. Modelled effects of primary and secondary production enhancement by seamounts on local fish stocks. Deep Sea Res. II. 2009, 56, 2713-2719. [CrossRef]

26. Sutton, T.T.; Porteiro, F.M.; Heino, M.; Byrkjedal, I.; Langhelle, G.; Anderson, C.I.H.; Horne, J.; Søiland, H.; Falkenhaug, T.; Godø, O.R.; et al. Vertical structure, biomass and topographic association of deep-pelagic fishes in relation to a mid-ocean ridge system. Deep Sea Res. II 2008, 55, 161-184. [CrossRef]

27. Maxwell, S.M.; Frank, J.M.; Breed, G.A.; Robinson, P.W.; Simmons, S.E.; Crocker, D.E.; Gallo-Reynoso, J.P.; Costa, D.P. Benthic foraging on seamounts: A specialized foraging behavior in a deep-diving pinniped. Mar. Mammal Sci. 2012, 28, E333-E344. [CrossRef]

28. Scales, K.L.; Miller, P.I.; Hawkes, L.A.; Ingram, S.N.; Sims, D.W.; Votier, S.C. On the Front: Frontal zones as priority at-sea conservation areas for mobile marine vertebrates. J. Appl. Ecol. 2014, 51, 1575-1583. [CrossRef]

29. Ruiz, J.; Echevarría, F.; Font, J.; Ruiz, S.; García, E.; Blanco, J.M.; Jiménez-Gómez, F.; Prieto, L.; González-Alaminos, A.; García, C.M.; et al. Surface distribution of chlorophyll, particles and gelbstoff in the Atlantic jet of the Alborán Sea: From submesoscale to subinertial scales of variability. J. Mar. Syst. 2001, 29, 277-292. [CrossRef]

30. Duffy, G.A.; Lundsten, L.; Kuhnz, L.A.; Paull, CK. A comparison of megafaunal communities in five submarine canyons off Southern California, USA. Deep Sea Res. II 2014, 104, 259-266. [CrossRef]

31. Sautya, S.; Ingole, B.; Ray, D.; Stöhr, S.; Samudrala, K.; Samudrala, K.; Raju, K.A.K.; Mudholkar, A. Megafaunal Community Structure of Andaman Seamounts Including the Back-Arc Basin - A Quantitative Exploration from the Indian Ocean. PLoS ONE 2011, 6, e16162. [CrossRef] [PubMed]

32. Renault, L.; Oguz, T.; Pascual, A.; Vizoso, G.J.; Tintore, J. Surface circulation in the Alborán Sea (western Mediterranean) inferred from remotely sensed data. J. Geophys. Res. 2012, 117, C08009. [CrossRef]

33. León, P.; Blanco, J.M.; Flexas, M.M.; Gomis, D.; Reul, A.; Rodríguez, V.; Jiménez-Gómez, F.; Allen, J.T.; Rodríguez, J. Surface mesoscale pico-nanoplankton patterns at the main fronts of the Alboran Sea. J. Mar. Syst. 2015, 143, 7-23. [CrossRef]

34. Tintoré, J.; La Violette, P.E.; Blade, I.; Cruzado, A. A study of an intense density front in the Eastern Alboran Sea: The Almeria-Oran Front. J. Phys. Oceanogr. 1988, 18, 1384-1397. [CrossRef]

35. Spalding, M.D.; Fox, H.E.; Allen, G.R.; Davidson, N.; Ferdaña, Z.A.; Finlayson, M.; Halpern, B.S.; Jorge, M.A.; Lombana, A.; Lourie, S.A.; et al. Marine ecoregions of the world: A bioregionalization of coast and shelf areas. BioScience 2007, 57, 573-583. [CrossRef]

36. Galarza, J.A.; Carreras-Carbonell, J.; Macpherson, E.; Pascual, M.; Roques, S.; Turner, G.F.; Rico, C. The influence of oceanographic fronts and early-life-history traits on connectivity among littoral fish species. Proc. Natl. Acad. Sci. USA 2009, 106, 1473-1478. [CrossRef] [PubMed]

37. Muñoz, M.; Reul, A.; Plaza, F.; Gómez-Moreno, M.-L.; Vargas-Yañez, M.; Rodríguez, V.; Rodríguez, J. Implication of regionalization and connectivity analysis for marine spatial planning and coastal management in the Gulf of Cadiz and Alboran Sea. Ocean Coast. Manag. 2015, 118, 60-74. [CrossRef]

38. Ban, C.N.; Maxwell, S.M.; Dunn, D.C.; Hobday, A.J.; Bax, N.J.; Ardon, J.; Gjerde, K.M.; Game, E.T.R.; Devillers, R.; Kaplan, D.M.; et al. Better integration of sectorial planning and management approaches for the interlinked ecology of the open oceans. Mar. Policy 2014, 49, 127-136. [CrossRef]

39. MEDAR Group. MEDATLAS/2002 Database: Mediterranean and Black Sea Database of Temperature Salinity and Bio-Chemical Parameters. Climatological Atlas [CD-ROM], Fr. Res. Inst. For Exploit. of Sea, Issy-Les-Moulineaux, France. 2002. Available online: http://www.ifremer.fr/medar/ (accessed on 1 May 2018).

40. Puertos del Estado. Available online: http://www.puertos.es/es-es/oceanografia/Paginas/portus.aspx (accessed on 28 July 2018).

41. Strickland, J.D.H.; Parsons, T.R. A Practical Handbook of Sea Waters Analysis. Bull. Fish. Res. Board Can. 1972, 167, 310.

42. Yentsch, C.M.; Menzel, D. A method for the determination of phytoplankton chlorophyll and phaeophytin by fluorescence. Deep Sea Res. 1963, 63, 221-231. [CrossRef] 
43. Bretherton, F.P.; Davis, R.E.; Fandry, R.E. A technique for objective analysis and design of oceanographic experiments applied to MODE-73. Deep Sea Res. Oceanogr. Abstr. 1976, 23, 559-582. [CrossRef]

44. Roemmich, D. Optimal estimation of hydrographic station data and derived fields. J. Phys. Oceanogr. 1983, 13, 1544-1549. [CrossRef]

45. Thiebaux, H.J.; Pedder, M.A. Spatial Objective Analysis with Applications in Atmospheric Sciences; Academic Press: New York, NY, USA, 1987; p. 299.

46. Pedder, M.A. Interpolation and filtering of spatial observations using successive corrections and Gaussian filters. Mon. Weather Rev. 1993, 121, 2889-2902. [CrossRef]

47. Gomis, D.; Ruiz, S.; Pedder, M.A. Diagnostic analysis of the 3D ageostrophic circulation from a multivariate analysis of CTD and ADCP Data. Deep Sea Res. I 2001, 48, 269-295. [CrossRef]

48. Hoskins, B.J.; Draghici, I.; Davies, H.C. A new look at the omega equation. Q. J. R. Meteorol. Soc. 1978, 104, 31-38. [CrossRef]

49. Tintoré, J.; Viúdez, A.; Gomis, D.; Alonso, S.; Werner, F.E. Mesoscale variability and Q vector vertical motion in the Alboran Sea. In Seasonal and Interannual Variability of the Western Mediterranean Sea; La Viollette, P.E., Ed.; Coastal Estuarine Studies; AGU: Washington, DC, USA, 1994; Volume 46, pp. 47-71. [CrossRef]

50. Konikow, L.F.; Bredehoeft, J.D. Computer Model of Two-Dimensional Solute Transport and Dispersion in Ground Water; USGS Techniques of Water Resources Investigations; US Government Printing Office: Washington, DC, USA, 1978; Volume 7, Chapter 2.

51. Deines, K.L. Backscatter estimation using broadband acoustic Doppler current profilers. In Proceedings of the IEEE Sixth Working Conference on Current Measurement, San Diego, CA, USA, 11-13 March 1999; pp. 249-253.

52. Kim, Y.H.; Voulgaris, G. Estimation of Suspended Sediment Concentration in Estuarine Environments Using Acoustic Backscatter for an ADCP. Coastal Sediments 2003. Available online: http:// citeseerx.ist.psu.edu/ viewdoc/download?doi=10.1.1.518.4449\&rep=rep1\&type=pdf (accessed on 30 September 2018).

53. Ahlstrom, E.H.; Thrailkill, J.R. Plankton Volume Loss with Time of Preservation. Rep. 9, Calif. Coop. Oceanic Fish. Invest., La Jolla, 1963, pp. 57-73. Available online: http:/ / calcofi.org/publications/calcofireports/v09/ Vol_09_Ahlstrom__Thrailkill.pdf (accessed on 28 July 2018).

54. Kane, J. Effect of season and location on the relationship between zooplankton displacement volume and dry weight in the Northwest Atlantic. Fish. Bull. 1982, 80, 631-642.

55. NOAA. ETOPO1 1 Arc-Minute Global Relief Model. Available online: https://maps.ngdc.noaa.gov/ viewers/wcs-client/ (accessed on 1 July 2018).

56. German Aerospace Center (DLR). “Deutsches Zentrum für Luft- und Raumfahrt” DLR EOWEB Interactive Data Service Demonstrator. Available online: https://centaurus.caf.dlr.de:8443/eoweb-ng/template/ default/welcome/entryPage.vm. (accessed on 5 May 2018).

57. Fiala, M.; Sournia, A.; Claustre, H.; Marty, J.-C.; Prieur, L.; Vetion, G. Gradients of phytoplankton abundance, composition and photosynthetic pigments across the Almeria-Orán front (SW Mediterranean Sea). J. Mar. Syst. 1994, 5, 223-233. [CrossRef]

58. Andersen, V.; Devey, C.; Gubanova, A.; Picheral, M.; Melnikov, V.; Tsarin, S.; Prieur, L. Vertical distribution of zooplankton across the Almería-Orán frontal zone (Mediterranean Sea). J. Plankton. Res. 2004, 26, 275-293. [CrossRef]

59. Fiedling, S.; Crisp, N.; Allen, J.T.; Hartmann, M.C.; Rabe, B.; Roe, H.S.J. Mesoscale subduction at the Almeria-Oran front: Part 2. Biophysical interactions. J. Mar. Syst. 2001, 30, 287-304. [CrossRef]

60. Prieur, L.; Sournia, A. “Almofront-1" (April-May 1991): An interdisciplinary study of the Almeria-Oran geostrophic front, SW Mediterranean Sea. J. Mar. Syst. 1994, 5, 187-203. [CrossRef]

61. L'Helguen, S.; Le Corre, P.; Madec, C.; Morin, P. New and regenerated production in the Almería-Oran front area, eastern Alboran Sea. Deep Sea Res. I 2002, 49, 83-99. [CrossRef]

62. Granata, T.C.; Estrada, M.; Zika, U.; Merry, C. Evidence for enhanced primary production resulting from relative vorticity induced upwelling in the Catalan Current. Sci. Mar. 2004, 68, 113-119. [CrossRef]

63. Prieto, L.; García, C.M.; Corzo, A.; Ruíz'Segura, J.; Echevarría, F. Phyoplankton, bacterioplankton and nitrate reductase activity distribution in relation to physical structure in the Northern Alborán Sea and Gulf of Cádiz (southern Iberian Peninsula). Bol. Inst. Esp. Oceanogr. 1999, 15, 401-411. 
64. Echevarría, F.; Zabala, F.; Corzo, A.; Navarro, G.; Prieto, L.; Macías, D. Spatial distribution of autotrophic picoplankton in relation to physical forcings: The Gulf of Cádiz, Strait of Gibraltar and Alborán Sea case study. J. Plank. Res. 2009, 31, 1339-1351. [CrossRef]

65. Revenga, S. The fisheries importance of four submarine canyons in the Spanish Mediterranean Sea: Cap de Creus, Palamós, Cape Tiñoso and Alborán platform canyons. In Mediterranean Submarine Canyons: Ecology and Governance; En Wütz, M., Ed.; UICN: Gland, Switzerland; Málaga, Spain, 2012; pp. 51-55.

66. Nieto, K.; Xu, Y.; Teo, S.L.H.; McClatchie, S.; Holmes, J. How important are coastal fronts to albacore tuna (Thunnus alalunga) habitat in the Northeast Pacific Ocean? Prog. Oceanogr. 2017, 150, 62-71. [CrossRef]

67. Camiñas, J.A.; (Instituto Español de Oceanografía, Centro Oceanográfico de Málaga, Andalucía, Spain). Personal communication, 2017.

68. Chapmann, D.C.; Haidvogel, D.B. Formation of Taylor caps over a tall isolated seamount in a stratified ocean. Geophys. Astrophys. Fluid Dyn. 1992, 64, 31-65. [CrossRef]

69. Pfannekuche, O. Benthic response to the sedimentati on of particulate organic matter at the Biotrans station, $47^{\circ} \mathrm{N}, 20^{\circ}$ W. Deep Sea Res. II 1993, 40, 135-149. [CrossRef]

70. Bollens, S.; Rollwagen-Bollens, G.; Quenette, J.A.; Bochdansky, A. Cascading migrations and implications for vertical fluxes in pelagic ecosystems. J. Plankton. Res. 2011, 33, 349-355. [CrossRef]

71. De Leo, F.C.; Smith, C.R.; Rowden, A.A.; Bowden, D.A.; Clark, M.R. Submarine canyons: Hotspots of benthic biomass and productivity in the deep sea. Proc. R. Soc. B 2010, 277, 2783-2792. [CrossRef] [PubMed]

72. Genin, A. Trophic focussing: The role of biophysical coupling in the formation of animal aggregation over abrupt topographies. J. Mar. Syst. 2004, 50, 3-20. [CrossRef]

73. Fernandez-Arcaya, U.; Ramirez-Llodra, E.; Aguzzi, J.; Allcock, A.L.; Davies, J.S.; Dissanayake, A.; Harris, P.; Howell, K.; Huvenne, V.A.I.; Macmillan-Lawler, M.; et al. Ecological role of submarine canyons and need for canyon conservation: A. Review. Front. Mar. Sci. 2017, 4, 5. [CrossRef]

74. Holthuis, L.B. FAO Species Catalogue Vol. 1-Shrimpa and Prawns of the World. An Annotated Catalogue of Species of Interest to Fisheries. 1980. FAO Fisheries Synopsis No. 125, Volume 1. Available online: http:/ / www.fao.org/docrep/009/ac477e/ac477e00.htm (accessed on 3 June 2017).

75. Puertos Pesqueros de Andalucía Garrucha. 2015 Consejería de Agricultura, Pesca y Desarrollo Rural Dirección General de Pesca y Acuicultura. Available online: https:/ /www.juntadeandalucia.es/export/ drupaljda/GARRUCHA-OCTUBRE-2017.pdf (accessed on 8 October 2018).

76. García-Rodríguez, M. La Gamba roja “Aristeus antennatus" (Risso, 1816) (Crustacea, Decapoda): Distribución, Demografía, Crecimiento, Reproducción y Explotación en el Golfo de Alicante, Canal de Ibiza y Golfo de Vera. Tesis Doctoral. Universidad Complutense de Madrid. 2003, p. 302. Available online: https: / / dialnet.unirioja.es/servlet/tesis?codigo=16761 (accessed on 7 March 2018).

77. Priede, I.G.; Godbold, J.A.; Niedzielski, T.; Collins, M.A.; Bailey, D.M.; Gordon, J.D.M.; Zuur, A.F. A review of the spatial extent of fishery effects and species vulnerability of the deep-sea demersal fish assemblage of the Porcupine Seabight, Northeast Atlantic Ocean (ICES Subarea VII). ICES J. Mar. Sci. 2011, 68, 281-289. [CrossRef]

78. Martín, J.; Puig, P.; Palanques, A.; Ribó, M. Trawling-induced daily sediment resuspension in the flank of a Mediterranean submarine canyon. Deep Sea Res. II 2014, 104, 174-183. [CrossRef]

79. Aguilar, R.; Pastor, X.; García, S.; Marin, P. Importance of Seamount-like features for conserving Mediterranean marine habitats and threated species. In Atlas of the Mediterranean Seamounts and Seamount-like Structures; Würtz, M.M., Rovere, M., Eds.; IUCN: Gland, Switzerland; Málaga, Spain, 2015; p. 276, ISBN 978-2-8317-1750-0.

80. Gofas, S.; Salas, C.; Taviani, M. Neopycnodonte Zibrowii World Register of Marine Species. 2009. Available online: http:/ / www.marinespecies.org/aphia.php?p=taxdetails\&id=379789 (accessed on 28 July 2018).

81. Vázquez, J.T.; Palomino, D.; Rovere, M.; Bo, M.; Alessi, J.; Fiori, C.; Würz, M. Seamounts and Seamounts-like structures of the Western Mediterranean. In Atlas of the Mediterranean Seamounts and Seamount-like Structures; Würtz, M.M., Rovere, M., Eds.; IUCN: Gland, Switzerland; Málaga, Spain, 2015; p. 276, ISBN 978-2-8317-1750-0. [CrossRef]

82. Tracey, D.M.; Clark, M.R.; Anderson, O.F.; Kim, S.W. Deep-Sea Fish Distribution Varies between Seamounts: Results from a Seamount Complex off New Zealand. PLoS ONE 2012, 7, E36897. [CrossRef] [PubMed] 
83. Moulins, A.; Rosso, M.; Nani, B.; Wurtz, M. Aspects of distribution of Cuvier's beaked whale (Ziphius cavirostris) in relation to topographic features in the Pelagos Sanctuary (north-western Mediterranean Sea). J. Mar. Biol. Assoc. UK 2007, 87, 177-186. [CrossRef]

84. Mors-Murphy, H.B. Submarine canyons as important habitat for cetaceans, with special reference to the Gully: A. review. Deep Sea Res. II 2014, 104, 6-19. [CrossRef]

85. D’amico, A.; Bergamasco, A.; Zanasca, P.; Carniels, S.; Nacini, E.; Portunato, N.; Teloni, V.; Mori, C.; Barbanti, R. Qualitative correlation of marine mammals with physical and biological parameters in the Ligurian Sea. IEEE J. Ocean. Eng. 2003, 28, 29-43. [CrossRef]

86. Podestá, M.; D'amico, A.; Pavan, G.; Drougas, A.; Komnenou, A.; Portunato, N. A review of Cuvier's beaked whale strandings in the Mediterranean Sea. J. Cetacean Res. Manag. 2006, 7, 251-261.

87. Azzellino, A.; Gaspari, S.; Airoldi, S.Y.; Nani, B. Habitat use and preferences of cetaceans along the continental slope and the adjacent pelagic waters in the western Ligurian Sea. Deep Sea Res. 2008, 55, 296-323. [CrossRef]

88. EMSA. European Maritime Safety Agency: Action Plan for Oil Pollution Preparedness and Response. In Proceedings of the 9th Meeting of the EMSA Administrative Board, Lisbon, Portugal, 21-22 October 2004; p. 67.

89. Zurita Manrubia, F.; Lara Pérez de Latsta, M.M.; San Martín Soga, M.; Segura Meléndez, M.M.; Pereiro Buenaventura, E.; Fernández Lora, M.; Gallé Cejudo, J.P. Localización de Zonas Idóneas Para el Desarrollo de la Acuicultura Marina en Andalucía; Junta de Andalucía. Consejería de Agricultura, Pesca y Desarrollo Rural: Sevilla, Spain, 2014; p. 163. Available online: http:/ / www.juntadeandalucia.es/servicios/publicaciones / detalle/77385.html (accessed on 1 May 2018).

90. DERA, Datos Espaciales de Referencia de Andalucía. 2015. Available online: https:/ / www.juntadeandalucia. es/institutodeestadisticaycartografia/DERA/ (accessed on 28 July 2018).

91. EurOBIS Data. European Node of the Ocean Biogeographic Information System. 2017. Available online: http: / / www.eurobis.org (accessed on 28 July 2018).

92. BOE. Resolución de 17 de Diciembre de 1999, de la Secretaría General de Medio Ambiente, Sobre la Evaluación de Impacto Ambiental de la Planta Desoladora de Agua de Mar de Carboneras, Almería, Promovida por la «Sociedad Estatal Aguas de la Cuenca del Sur, Sociedad Anónima». Ministerio de Medio Ambientere. 2000. Available online: http:/ / www.boe.es/diario_boe/txt.php?id=BOE-A-2000-2393 (accessed on 1 August 2018).

93. Martínez-Lage, A.V. Erosión Costera en Almería 1957-1995; Instituto de Estudios Almerienses: Almería, Spain, 2001; pp. 1-551, ISBN 978-8-48-108244-9.

94. Howard, M.D.A.; Kudela, R.M.; McLaughlin, K. 2017. New insights into impacts of anthropogenic nutrients on urban ecosystem processes on the Southern California coastal shelf: Introduction and synthesis. Estuar. Coast. Shelf Sci. 2017, 186, 163-170. [CrossRef]

95. Gierach, M.M.; Holt, B.; Trinh, R.; Pan, B.; Rains, C. Satellite detection of wastewater diversion plumes in Southern California. Estuar. Coast. Shelf Sci. 2017, 186, 171-182. [CrossRef]

96. Bianchi, C.N.; Morri, C. Marine Biodiversity of the Mediterranean Sea: Situation, Problems and Prospects for Future Research. Mar. Pollut. Bull. 2000, 40,367-376. [CrossRef]

97. BOJA. Decreto 314/1987 de 23 de Diciembre, de Declaración del Parque Natural de Cabo de Gata-Nijar. 1988. Available online: http:/ / www.juntadeandalucia.es/boja/1988/6/boletin.6.pdf (accessed on 28 July 2018).

98. BOJA. Decreto 493/2012, de 25 de Septiembre, por el Que se Declaran Determinados Lugares de Importancia Comunitaria Como Zonas Especiales de Conservación de la Red Ecológica Europea Natura 2000 en la Comunidad Autónoma de Andalucía. 2012. Available online: http:/ /www.juntadeandalucia.es/boja/2012/ 200/BOJA12-200-00029-16202-01_00014480.pdf (accessed on 9 June 2017).

99. BOE. Orden AAA/1366/2016, de 4 de Agosto, por la Que se Declaran Zonas Especiales de Conservación de Lugares de Importancia Comunitaria de la Región Marina Mediterránea de la Red Natura 2000, se Aprueban sus Correspondientes Medidas de Conservación y se Propone la Ampliación de los Límites Geográficos de dos Lugares de Importancia Comunitaria. 2016. Available online: https: / boe.vlex.es/vid/orden-aaa-13662016-646733925 (accessed on 1 August 2017). 
100. BOE. Orden AAA/2280/2014, de 1 de Diciembre, por la Que se Aprueba la Propuesta de Inclusión en la Lista de Lugares de Importancia Comunitaria de la Red Natura 2000 de los Espacios Marinos ESZZ12003 Sistema de Cañones Submarinos de Avilés, ESZZ16003 Sur de Almería-Seco de los Olivos, ESZZ16005 Espacio Marino de Alborán, ESZZ16004 Espacio Marino de Illes Columbretes y ESZZ15001 Banco de la Concepción. 2014. Available online: https:/ / boe.es/diario_boe/txt.php?id=BOE-A-2014-12628 (accessed on 1 August 2017).

101. Magris, R.A.; Andrello, M.; Pressey, R.L.; Mouillot, D.; Dalongeville, A.; Jacobi, M.N.; Manel, S. Biologically representative and well-connected marine reserves enhance biodiversity persistence in conservation planning. Conserv. Lett. 2018, 11, e12439. [CrossRef]

102. CAMP-LA. Coastal Area Management Programme Levante de Almería, a laboratory to test Integrated Coastal Zone Management. Ministrerio de Agricultura, Alimentación y Medio Ambiente. Conserjería de Agricultura, Pesca y Medio Ambiente. Junta de Andalucía. Deposito Legal: M.-997-2013. Spanish Version. 2013. Available online: https://www.pap-thecoastcentre.org/pdfs/levante_almeria_laboratory $\% 20$ to $\%$ 20test\%20ICZM.pdf (accessed on 26 July 2018).

103. Johnston, P.; Santillo, D. Conservation of Seamount Ecosystems: Application of the MPA Concept. Annual ICES Science Conference, Copenhgaguen. CM 2002, M14. Available online: www.ices.dk/sites/pub/CM\% 20Doccuments/2002/M./M1402.PDF (accessed on 28 July 2018).

104. Schlachter, T.A.; Rowden, A.A.; Dower, J.F.; Consalvey, M. Seamount science scales undersea mountains: New research and outlook. Mar. Ecol. 2010, 31, 1-13. [CrossRef]

105. Davies, J.S.; Howell, K.L.; Stewart, H.A.; Guinan, J.; Golding, N. Defining biological assemblages (biotopes) of conservation interest in the submarine canyons of the South West Approaches (offshore United Kingdom) For use in marine habitat mapping. Deep Sea Res. II 2014, 104, 208-229. [CrossRef]

106. Clark, M.R.; Watling, L.; Rowden, A.A.; Guinotte, J.M.; Smith, C.R. A global seamount classification to aid scientific design of marine protected networks. Ocean Coast. Manag. 2011, 54, 19-36. [CrossRef]

107. Alemany, F. Spatial Management to Support Recovery of the Atlantic Bluefin Tuna in the Mediterranean; The Case for Implementing a Bluefin Tuna Sanctuary (or Permanent Fishing Closure) in the Balearic Sea; Report; WWF Mediterranean: Palna de Mallorca, Spain, 2008; pp. 1-31. Available online: http:/ /assets.panda.org/ downloads/balearic_islands_sanctuary_report_wwf.pdf (accessed on 7 March 2018).

108. Ministerio de Fomento. Fomento Pone en Servicio el Nuevo Dispositivo de Separación de Tráfico de Buques en Cabo de Gata. 2006. Available online: http:/ / www.fomento.gob.es/NR/rdonlyres/AED35ED5-32E84661-848B-D8E6BEAA4F2F/63138/0611301.pdf (accessed on 5 June 2017).

109. Final Report of the Workshop: First IMMA Regional Workshop for the Mediterranean, Chania, Greece, 24-28 October 2016; 29p. Available online: https://www.marinemammalhabitat.org/download/reportregional-workshop-mediterranean-important-marine-mammal-areas/ (accessed on 28 July 2018).

110. Hobday, A.J.; Maxwell, S.M.; Forgie, J.; McDonald, J.; Darby, M.; Seto, K.; Bailey, H.; Bogard, S.J.; Briscoe, D.K.; Costa, D.P.; et al. Dynamic Ocean Management: Integrating scientific and technological capacity with law, policy and management. Stanf. Environ Law. J. 2014, 33, 125-165.

111. Álvarez-Romero, J.G.; Pressey, R.L.; Ban, N.C.; Brodie, J. Advancing Land-Sea Conservation Planning: Integrating Modelling of Catchments, Land- Use Change, and River Plumes to Prioritise Catchment Management and Protection. PLoS ONE 2015, 10, E0145574. [CrossRef] [PubMed]

112. Intemares. Nota Informativa Extendida del Proyecto Life IP Intemares. 2018. Available online: www.awasassets. wwf.es/downloads/Nota_informativa_ext_LIFE_IP_INTEMARES.pdf (accessed on 20 September 2018).

113. IDAPES. Sistema de Información Andaluz de Comercialización y Producción Pesquera. Conserjería de Agricultura, Pesca y Desarrollo Rural. 2018. Available online: http://www.juntadeandalucia. es/agriculturaypesca/idapes / servlet/FrontController?action=ConsultarPrecios\&optSel=origen\&ec= observatorio\&id_menu=menu_1 (accessed on 17 March 2018).

114. Cazalla, E.; Casado, J.; Catalá, T.; Tilot, V.; Bernal, C. Assessment of Whale Watching Activities in the Gibraltar Strait. 2016, p. 66. Available online: http://www.accobams.org/new_accobams/wp-content/uploads/ 2017/05/MOP6.Inf11.pdf (accessed on 30 September 2018).

115. Giakoumi, S.; Scianna, C.; Plass-Johnson, J.; Micheli, F.; Grorud-Colvert, K.; Thiriet, P.; Claudet, J.; Di Carlo, J.; Di Franco, A.; Gaines, S.D.; et al. Ecological effects of full and partial protection in the crowded Mediterranean Sea: A regional meta-analysis. Sci. Rep. 2017, 7, 8940. [CrossRef] [PubMed] 
116. Goñi, R.; Hilborn, R.; Díaz, D.; Mallol, S.; Adlerstein, S. Net contribution of spillover from a marine reserve to fishery catches. Mar. Ecol. Prog. Ser. 2010, 400, 233-243. [CrossRef]

117. Directive 2008/56/EC of the European Parliament and of the Council of 17 June 2008 Establishing a Framework for Community Action in the Field of Marine Environmental Policy (Marine Strategy Framework Directive) (Text with EEA Relevance). Available online: https://eur-lex.europa.eu/legal-content/EN/TXT/ ?uri=CELEX\%3A32008L0056 (accessed on 15 June 2018).

118. Directive 2014/89/EU of the European Parliament and of the Council of 23 July 2014 Establishing a Framework for Maritime Spatial Planning. Available online: https://eur-lex.europa.eu/legal-content/ EN/TXT/?uri=uriserv:OJ.L._.2014.257.01.0135.01.ENG (accessed on 28 July 2018).

119. Directive 2000/60/EC of the European Parliament and of the Council of 23 October 2000 Establishing a Framework for Community Action in the Field of Water Policy. Available online: https:/ / eur-lex.europa.eu/ legal-content/en/ALL/?uri=CELEX:32000L0060 (accessed on 15 June 2018).

120. Blue Growth. Opportunities for Marine and Maritime Sustainable Growth (Text with EEA Relevance). Communication from the Commission to the European Parliament, the Council, the European Economic and Social Committee and the Committee of the Regions. Brussels 13.9.2012, COM (2012) 494 Final. Available online: https:/ / ec.europa.eu/maritimeaffairs/publications/blue-growth-opportunities-marineand-maritime-sustainable-growth_it (accessed on 28 July 2018).

121. European Commission. Commission Staff Working Document Report on the Blue Growth Strategy Brussels, 31.3.2017 SWD (2017) 128 Final. 2017. Available online: https://ec.europa.eu/maritimeaffairs/sites/ maritimeaffairs / files/swd-2017-128_en.pdf (accessed on 28 July 2018).

(C) 2018 by the authors. Licensee MDPI, Basel, Switzerland. This article is an open access article distributed under the terms and conditions of the Creative Commons Attribution (CC BY) license (http:// creativecommons.org/licenses/by/4.0/). 